IFN Working Paper No. 916, 2012

\title{
Why the WTO? An Introduction to the Economics of Trade Agreements
}

Gene M. Grossman and Henrik Horn 


\title{
Why the WTO? \\ An Introduction to the Economics of Trade Agreements
}

\author{
by \\ Gene M. Grossman \\ Princeton University \\ Henrik Horn \\ Research Institute of Industrial Economics, Stockholm
}

April 28, 2012

This study is written for the American Law Institute project Legal and Economic Principles of World Trade Law. It builds on joint work, and many discussions, with Kyle Bagwell and Robert W. Staiger. We have also greatly benefited from many exchanges with Wilfred J. Ethier and Donald Regan. Don also provided very helpful comments on an earlier draft, as did Evan Wallach. We are extremely grateful for financial support from the Jan Wallander and Tom Hedelius Research Foundation, Svenska Handelsbanken, Stockholm, and from the Milton and Miriam Handler Foundation, USA 


\section{Contents}

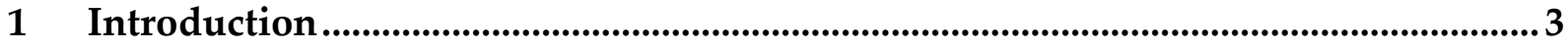

2 Building Blocks for a Theory of Trade Agreements.....................................................6

2.1 Economic Interdependence and International Externalities ...................................7

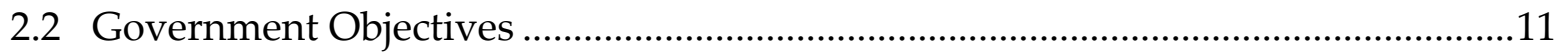

2.3 A Formal Representation of Government Objectives .............................................14

2.4 Predicting Outcomes of Strategic Interaction......................................................15

3 A General International Externalities Model of Trade Agreements ........................ 17

3.1 Imposing Minimal Structure on Government Objectives ......................................18

3.2 The Benchmark Outcome: Unilateral Policy Decisions ..........................................19

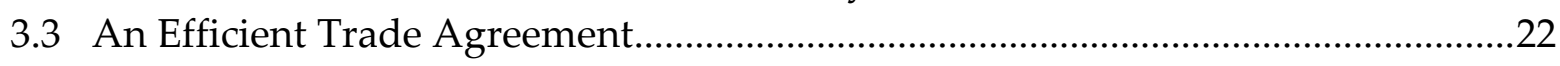

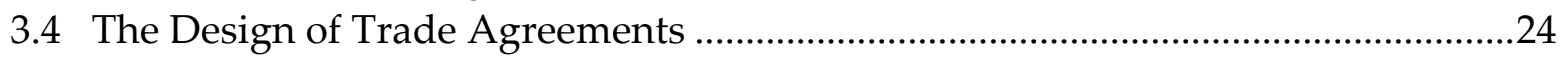

3.4.1 Trade Agreements Are Negotiated .................................................................25

3.4.2 Trade Agreements Must Be Self-Enforcing ....................................................26

3.4.3 Trade Agreements Are Explicit and Incomplete ..............................................29

3.4.4 Trade Agreements Involve Reciprocal Exchanges of Concessions ...................31

4 A Special Case: The National Market Power Model ................................................31

4.1 When Free Trade Is Unilaterally Optimal...............................................................32

4.2 The Unilateral Incentive to Exploit National Market Power ...................................33

4.3 The Basic National Market Power Model ..................................................................36

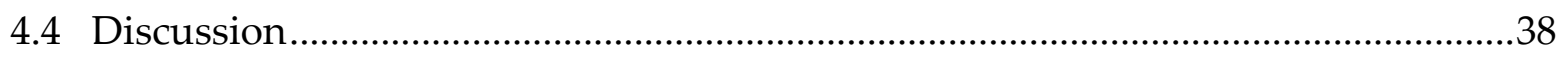

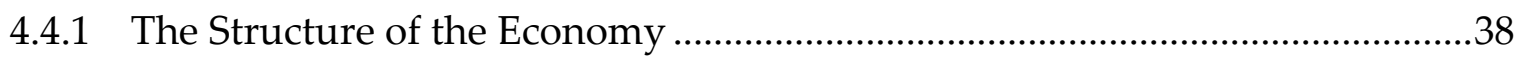

4.4.2 Do Countries Have Sufficient Market Power? .....................................................39

4.4.3 Richer Descriptions of the Politics of Trade-Policy Formation..........................41

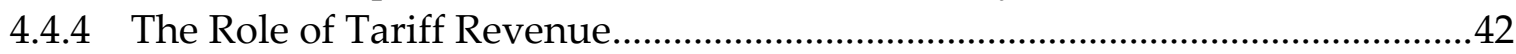

4.4.5 Labeling the Government Behavior That Trade Agreements Address...........43

4.5 Are Predictions from the National Market Power Model Compatible with the Design of the GATT? ......................................................................................................45

4.5.1 Border Instruments Are Regulated, But Alternative Policies Are Treated

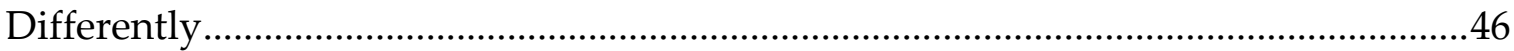

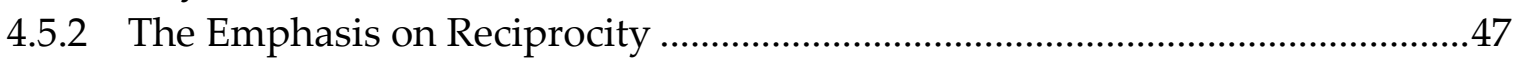

4.5.3 Border Instruments Are Regulated, But Domestic Instruments Are Not .......48

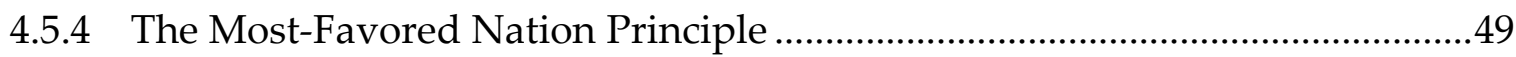

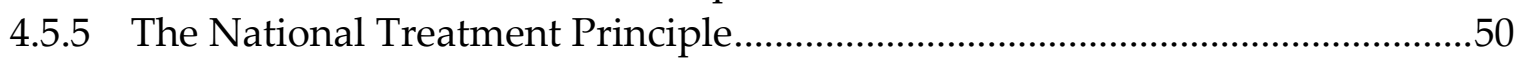

4.5.6 Rules Concerning Preferential Trading Agreements ........................................50

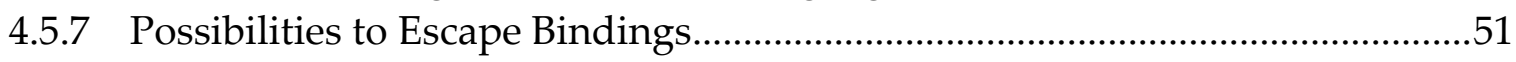

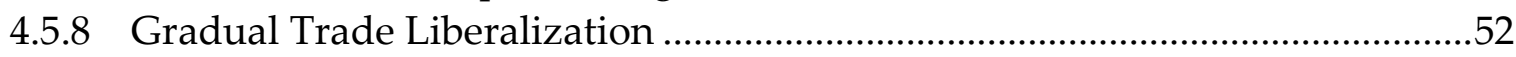




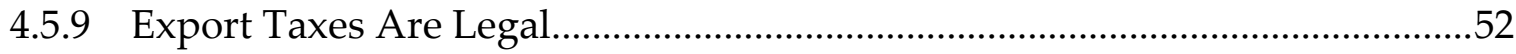

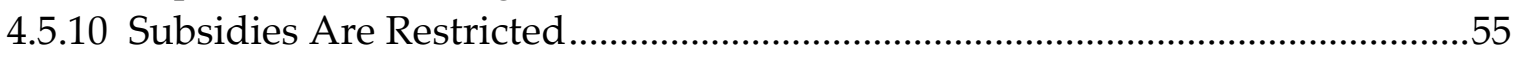

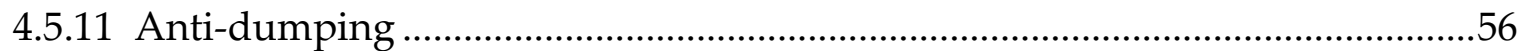

5 Trade Agreements as Government Commitment Devices Vis-à-Vis Constituent

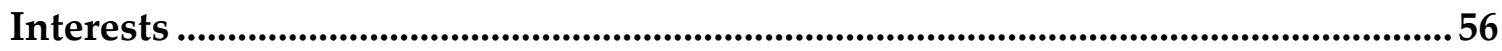

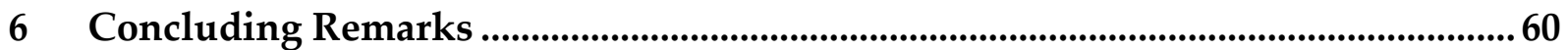

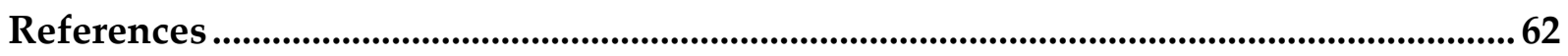




\section{Introduction}

This study is part of The American Law Institute (ALI) project Legal and Economic Principles of World Trade Law. The project aims to analyze the central instrument in the World Trade Organization (WTO) Agreement for the regulation of trade in goods-The General Agreement on Tariffs and Trade (GATT). The present study is one of two background studies for this project. ${ }^{1}$ The first study, The Genesis of the GATT, appraises the rationale for the creation of the GATT, and tracks its development from a historical and legal perspective. This second study provides an overview of the economics of trade agreements.

A distinguishing feature of this ALI project is the desire to base the analysis of the GATT firmly in both economics and law. The necessity of legal analysis needs no justification. But why also base the study in economics? Art. 31.1 of the Vienna Convention of the Laws of Treaties states that an international agreement should be interpreted "in the light of its object and purpose." There are fundamental reasons why the interpretation of the GATT therefore cannot be adequately addressed without economic analysis. First, we will discuss below the possible purposes of the agreement in much greater detail, but for now let us just quote the Preamble to the GATT, to show that the objectives of the GATT are expressed in inherently economic terms:

... Recognizing that their relations in the field of trade and economic endeavour should be conducted with a view to raising standards of living, ensuring full employment and a large and steadily growing volume of real income and effective demand, developing the full use of the resources of the world and expanding the production and exchange of goods,...

Furthermore, these objectives are linked to the policies that the GATT regulates through the operation of markets. It is clearly necessary to understand these mechanisms in order to appropriately interpret the agreement, and this in turn requires economic analysis. Hence, an appreciation of both the objectives of the GATT and the mechanisms by which its stipulations further those objectives requires that the analysis is based in economics. An analysis of the GATT that relied solely on a traditional legal perspective would be inadequate.

The need for a joint economic and legal analysis of the GATT implies that the analysis must be undertaken jointly by economists and lawyers. Such collaboration requires an

\footnotetext{
1 There is a second leg to the ALI project, in which economists and lawyers jointly analyze the emerging case law from the WTO dispute-settlement mechanism.
} 
understanding among economists of the law and of legal analysis, and a corresponding understanding among lawyers of fundamental economic concepts and reasoning. The purpose of this second background study is to lay out to readers with little or no training in economics (but with sufficient patience and intellectual curiosity), the perspective that most trade economists bring to the study of trade agreements, in general, and the GATT in particular. The aim is not to provide a comprehensive survey of the literature on trade agreements, nor to evaluate the relative importance of the contributions to the literature, but rather to sketch some of the basic underlying principles. ${ }^{2}$ To this end, the study focuses on the main analytical approach to the study of trade agreements, largely putting other approaches aside, irrespective of their intellectual merits.

To illustrate the importance of understanding the purpose of the agreement when interpreting it, consider the role of a safeguard provision that allows a country to temporarily exceed its tariff binding for an industry, provided that the industry has suffered "serious injury" as a consequence of increased imports. How should the word "serious" be interpreted in this context? The answer depends on what the GATT Member governments are trying to achieve. If, with the creation of the GATT, governments hoped to achieve more liberal trade but needed assurances that they could "escape" from negotiated commitments if unanticipated events later occurred, then economic arguments would suggest caution in interpreting the serious-injury standard too stringently, lest governments, fearing the "straightjacket" that GATT commitments might then imply, would be hesitant to accept tariff commitments in the first place. If, instead, governments hoped to "tie their hands" with GATT commitments, so that when later faced with protectionist pressures they could resist offering palliatives, then a "straightjacket" would be exactly what the governments would have hoped to achieve with their GATT commitments. In this case, economic arguments would counsel caution in interpreting the serious-injury standard too permissively. Consequently, we are led to very different conclusions depending on the assumed role of the agreement.

Finally, even if one accepts the importance of being clear about the purposes of the GATT, one might question the need for deep analysis of this matter. Is it not obvious that the purpose of the GATT simply is to facilitate maximal exploitation of the gains from international trade in their various forms? While it is certainly true that governments often are willing to liberalize trade in order to reap the benefits from international exchange, the matter must be more subtle than this. If governments cared only about reaping the efficiency gains from trade, there would be little need for an international

2 Surveys of various strands of the literature can be found in, e.g., Bagwell and Staiger (2002), Ethier (2010), Hoekman and Kostecki (2009), Magee (1994), Nelson (1988), Schropp (2009), Rodrik (1995), Staiger (1995), and WTO (2008). 
agreement. Instead, the governments could practice unilateral free trade and otherwise let goods flow where they may. The fact that governments actively pursue a myriad of policies that alter the incentives to trade already suggests that their goals are more nuanced. The very complexity of the GATT suggests that multiple objectives are at play and that governments' motives are not obvious. This observation is compounded by the apparent incongruity between standard economic arguments in favor of completely free trade and the manner in which governments approach their negotiations under the umbrella of the GATT. Evidently, clarifying the underlying purpose(s) of the GATT and articulating a reason for the GATT to exist is not as simple a task as it might first appear. In what follows, we will present and critically discuss the standard approach in economics to explaining the rationale for agreements such as the GATT.

The structure of this study is as follows. Section 2 introduces several economic concepts that will be essential for the analysis to come. It starts by discussing the notion of an "externality." Most economists believe that trade agreements are made to address the negative international externalities that would result if governments were to set their trade policies unilaterally and without regard to their effects on actors in other countries. We then provide an introduction to the conceptually difficult idea of a "government objective function." Finally, we present the basic game-theoretic concept, that economists and others use to predict the outcomes of strategic interaction in the absence of a cooperative agreement - the "Nash equilibrium."

In Section 3, we introduce a stylized model of a trade agreement that is general enough to encompass the majority of models in the literature as special cases. This section also discusses a number of general features of trade agreements, such as their reciprocal nature, the importance of the fact that they are negotiated settlements, the need for agreements to be self-enforcing, the inevitable contractual incompleteness of trade agreements, and the fact that trade agreements are manifestly textual documents.

The generality of the model in Section 3 helps us to distill the commonality of a large part of the literature on trade agreements. But it has the consequence of depriving the model of more specific predictions with regard to many aspects of interest. In particular, there is very little of economic structure imposed on the model, so the model does not illuminate the exact economic reasons for the existence of trade agreements. Section 4 goes to the opposite extreme, and imposes several strong assumptions about market structure and government motives on the general model. This particular model, which we shall term the "national market power model," has been well developed in the economics literature, and rightfully it has been very influential in shaping the way that many economists think about trade agreements. But some observers remain dubious about the empirical plausibility of some underlying assumptions of the national market power model and so 
question whether it can provide a meaningful explanation for the GATT. Section 4 discusses their critique, and also broadly assesses the extent to which the model helps to explain core features of the GATT.

Section 5 lays out the so-called "commitment approach" to explaining the role of trade agreements. It sees trade agreements as means for governments to tie their own hands vis-à-vis their domestic interest groups. This commitment approach is often portrayed as the leading alternative to the international externalities approach. As we will explain, however, we believe that the two approaches are better seen as complementary.

Section 6 concludes.

\section{Building Blocks for a Theory of Trade Agreements}

In order to lay the groundwork for the analysis of trade agreements that follows, this section will discuss several fundamental concepts that feature prominently in any economic analysis of trade-policy formation. In Section 2.1 we focus on the economic interdependence between countries in a global world economy. Most explanations for why countries enter into trade agreements cite the economic interdependence between national economies as an important motivating consideration. When national economies are mutually interdependent, governments' decisions about trade and other policies will have repercussions outside their national borders, and these repercussions may be downplayed or ignored if the governments act noncooperatively. Interdependencies exist whenever private actions and public policies in one country affect economic (and other) outcomes elsewhere. Such spillover effects are pervasive in today's world economy, and increasingly so with the globalization of so many areas of economic interaction.

Government decisions, and the scope for beneficial trade agreements, do not only depend on the way in which policy choices affect economic variables at home and abroad, but also on how the governments evaluate these effects. Section 2.2 will discuss the treatment of government objectives and motives in models of trade agreements.

Finally, having described how decisionmakers' policy choices are mutually interrelated, and how their respective decision problems can be mathematically represented as optimizations of well-specified objective functions with certain properties, it is natural to ask what will be the outcome of these governmental interactions. This is not a trivial issue, because each decisionmaker's optimal choice of policy depends on the choices of the other decisionmakers. Section 2.4 introduces the concept of a Nash Equilibrium, 
which game theorists use to forecast the outcome of strategic interactions such as those that interdependent governments face when setting their economic policies.

\subsection{Economic Interdependence and International Externalities}

In earlier times, national economies (and even local economies) were geographically isolated. The difficulty of moving people, goods, and information meant that there was little migration from one region to another, little trade of goods, services, and capital, and little exchange of information and ideas. But with the falling costs of transportation and communication came an expanding web of economic relations. Goods farmed or manufactured in one location increasingly were shipped for consumption far from their place of production. People relocated from their nation of birth to pursue economic opportunities on distant continents. International lending provided additional sources of funding for investment beyond what could be financed with local savings. Ideas flowed from their place of creation via communication and imitation. These processes of globalization have been ongoing for centuries, and continue today. And, most recently, improved information technologies have made possible the remote delivery of services that formerly required face-to-face contact.

When residents of different countries exchange goods, services, capital, information, and ideas, the outcomes in any location are determined in part by conditions and actions elsewhere. Planting decisions in New Zealand affect the price of food in Australia. A savings glut in Japan encourages new investment in Thailand. An invention in Spain finds uses in Argentina. French films are enjoyed by moviegoers in Canada. Indian call centers respond to queries from American customers, while perhaps displacing U.S. workers from their similar jobs.

The increasing integration of national economies does not as such suffice to explain the development of multilateral trade agreements, such as the GATT and the WTO, because these agreements constrain the actions of politicians and bureaucrats, not those of actors in the private sector. Do government policies have spillover effects that might warrant some strictures in the name of international cooperation? Surely they do. Policies that restrict imports or promote exports most obviously have implications for incomes and prices abroad. Domestic policies also affect foreign citizens in a world of economic interdependence. A farm subsidy or tax on gasoline or a regional development loan will alter the allocation of resources domestically and so generate spillover effects abroad. The spillover effects of all sorts of national laws, regulations, and bureaucratic procedures provide the most plausible explanation for international agreements, including trade agreements. 
At this point, we need to introduce a few fundamental economic concepts. First, economists use measures of "efficiency" in policy analysis to gauge which changes in policy are beneficial or harmful to society. There are alternative notions of economic efficiency that differ according to whether they contemplate the possibility of compensation in combination with the policy change, or whether the policy effects are considered all on their own. The Pareto criterion considers as unambiguously beneficial only those policy changes that make some individuals better off without harming any others, when the policy change is taken in isolation from any forms of compensation. Needless to say, this is a very strict criterion for efficiency gain inasmuch as most policy choices create winners and losers. A more forgiving measure of efficiency is that proposed by Kaldor and Hicks. According to the Kaldor-Hicks criterion, a policy change is considered efficiency enhancing if the winners gain more than the losers give up, in the sense that it would be possible to transfer resources ex post from the direct winners to the direct losers in such a way that no one is left worse off than before the policy change. The Kaldor-Hicks criterion is more common in policy analysis because it corresponds to the intuitive idea that policy change is (potentially) good for society if it "expands the size of the economic pie."

Second, economists use the term "externalities" to refer to the consequences of actions taken within a relationship for those on the outside. The consequences can be beneficial or harmful, giving rise to externalities that are "positive" or "negative," depending on whether they benefit the third parties or not. Externalities pose a problem for economic efficiency; whereas the parties to a relationship have means to influence actions that affect their interests (by, for example, offering or withholding payments or other counteractions), the interests of those outside a relationship can easily be overlooked in the course of decisionmaking. ${ }^{3}$ Where government policies are concerned, the relationship at stake is between the politicians who set the policies (and the bureaucrats who implement them) on the one hand, and their domestic constituencies such as voters and interest groups on the other. Foreign citizens are external to these political relationships, so there is no direct mechanism for their interests to be taken into account. International negotiations and agreements are a means to "internalize" the externalities that flow from national politics, that is, to make decisionmakers behave as if they took these beneficial or adverse external effects into account.

A distinction is sometimes drawn between "real" and "pecuniary" externalities. Real externalities flow directly from an action, such as when poisonous waste is deposited in a

3 The term "efficiency" refers, roughly speaking, to the extent to which the maximum benefit is obtained from a relationship. 
river, thereby affecting individuals who live or work downstream. A pecuniary externality, by contrast, is mediated by the price system; when a consumer buys an ear of corn, the consumption of the corn itself causes no harm to others, but the purchase may bid up the price of corn and so make it more expensive for others to consume. The distinction between the two types of externalities is useful in some contexts. However, the distinction carries less meaning in the context of government actions affecting world trade, since both forms of externalities can give rise to inefficiencies. Real externalities certainly are a cause for concern to the world economy, such as when greenhouse gases generated in one country cause environmental damage elsewhere. But activities by governments that cause world prices of certain goods to rise or fall can also generate inefficiencies for foreign interests, and in this sense generate (international) externalities.

There is an obvious reason why externalities can arise when governments set their trade policies: national governments often place little or no weight on the well-being of foreigners in making their policy choices. Take for example a policy that has some adverse effects on a group of consumers or firms. If the group is a domestic one, then presumably the government would weigh the harm in choosing its policy level. But if the group is foreign, there are fewer if any political mechanisms to ensure that this is so. As a result, there will be a tendency to overuse policies that generate costs abroad, and underuse those that are beneficial there. Unilateral policy choices are therefore likely to be inefficient when evaluated from the perspective of the world as a whole.

For example, consider some French policy that would cause the world price of wine to rise. If all wine consumers and producers resided in France, then the French government might consider the price hike to be roughly a "wash." The extra cost to French consumers would be matched by a similar rise in producer revenues and if the government weighed the two equally, it might consider this to be neither a gain nor a loss. However, we know that France, in fact, is a substantial exporter of wine, which means that its farms produce more than its households drink. It follows that French producers gain more in revenues when prices go up than French consumers pay in extra outlays. The consumer losses are, of course, shared by wine lovers abroad. Now if, as is likely to be the case, the French government puts less weight on the interests of the foreigners than on those of French citizens, it could well see the increase in wine price as bringing benefit to France. Consequently, its policies that affect wine prices would be inefficient from a global perspective. But France might be open to the idea that it changes its policies in exchange for similar concessions by foreign governments in other markets. We will see that externalities that are transmitted through world prices play a central role in the literature on trade agreements. 
When governments neglect the impact of their national policies on their trading partners, they are likely to set their policies at inefficient levels even when the interventions themselves are justifiable in terms of global efficiency. Consider, for example, a situation in which the consumption of some product generates an adverse impact on the environment. In such circumstances, the government would be well justified to discourage consumption via taxation and, indeed, a consumption tax at some level would serve to improve global efficiency. However, if when choosing its tax rate, the government ignores the fact that the tax will harm producer interests in foreign, exporting countries, it is bound to choose a tax rate higher than the one associated with a globally efficient outcome. The globally optimal consumption tax balances the benefits to the local environment with the cost to producers wherever they are located, and if some produce interests are ignored, the resulting tax will be overly stringent from a global point of view.

Unilateral policy setting can also result in inefficiency in governments' discrete choices. Suppose, for example, that a national government must rule on whether a corporate merger is permissible under its national competition laws. In making this decision, the efficiency-minded government would weigh the harm to consumers resulting from any greater exploitation of market power against the benefit to the firms from any technological synergies or other productivity gains that might result from the combination. If all the parties to the proposed merger are national companies, then a consideration of national consumer and producer interests alone might be sufficient for a decision that promotes the efficient outcome. However, if some of the parties to the merger are foreign firms, and if the potential gains to these firms do not figure in the government's cost-benefit calculus, then the resulting decision on the merger might err on the side of conservatism; that is, they might disallow mergers that would, if tolerated, create (global) gains in excess of the costs to consumers. An international agreement on competition policy would be needed to ensure globally efficient decisions. ${ }^{4}$

In order for a unilateral policy to be internationally inefficient, it obviously must affect foreign interests. But an adverse international impact does not necessarily make a government's domestic policy inefficient. This can be seen in the example above in which consumption of an imported product pollutes the environment. Global efficiency can be

\footnotetext{
4 The commitment approach (to be discussed in Section 5) suggests that trade agreements are vehicles by which governments can commit to implement policies that might run against their short-run interests at the time when they must be carried out. But even this explanation for trade agreements requires interdependence. First, partners to an agreement would not play a role in enforcing a government's commitments if economic outcomes in their countries did not depend on the policies enacted by the government that seeks to tie its own hands. Second, a government will not be able to use a trade agreement as a vehicle for commitment unless it is concerned about the retaliatory policies that would be imposed by partners to the agreement, should it fail to honor its commitment.
} 
achieved in the presence of pollution externalities by means of a consumption tax. Such a tax can further efficiency even though it may harm producers in a foreign country. It is thus not the adverse effect on foreign interests per se that makes a government action inefficient, but rather the failure to consider these interests in setting the level of the policy. A consumption tax will be globally inefficient in our example of a pollution externality only if the tax rate is higher than what is required to balance the effects on all interests, both local and foreign. The need to balance costs and benefits for various parties complicates the interpretation and implementation of a number of GATT features, including the provisions for National Treatment.

\subsection{Government Objectives}

Trade negotiations are conducted by officials appointed by their national governments. To predict the outcome of a negotiation, and to interpret the meaning of the language of the agreement, we need to understand the objectives of these negotiators. ${ }^{5}$ More generally, whose preferences do negotiators represent? And how do legislators evaluate and rank alternative policies?

These are difficult questions that have perplexed economists and political scientists for decades. It is tempting to argue that negotiators in a democracy represent the aggregate preferences of society. But how do we aggregate individuals' preferences? How much weight do the views of a particular person receive? Should we weigh individuals equally in some sense? If so, how do we deal with the fact that the intensity of an individual's preferences is a personal matter and impossible to compare to that of another? Suppose citizen 1 in country A would very much like a trade agreement with some given terms, but is less enthusiastic about another agreement. Meanwhile, citizen 2 has the opposite ordering. What are the preferences of society? Even if we expect a compromise between the two, exactly which compromise would we expect the negotiator to seek? If the negotiator cannot deliver her preferred agreement because the negotiator for country $B$ has different goals, how will the negotiators evaluate the various possible compromises between their two first choices? These questions have been at the forefront in social-choice theory, a field of economics, political science, and moral philosophy. The theory has produced many interesting arguments but no compelling resolution to these issues.

The simplest approach-and also the most commonly used approach in the economics literature-assumes that each government seeks to maximize the sum of the incomes of all of its citizens. However, it is difficult to justify national income as the appropriate

\footnotetext{
${ }^{5}$ In our discussion below, we do not draw a distinction between the preferences of the government officials who negotiate a trade agreement and those of the government officials who select trade policies after the agreement is in place. See Section 5 for a discussion of this assumption.
} 
government objective either descriptively or prescriptively. As a description of government objectives, simple income measures are suspect because they neglect citizens' concerns about the prices of the goods they buy, the insecurity they feel about potential disruptions to their income flows, the conditions under which they work, the quality of their environment, and so on. As a prescription, the measures suffer from these same omissions and moreover they suggest a lack of societal concern about the distribution of income.

An alternative approach begins with the notion of a "social welfare function." Social welfare is intended to measure overall societal well-being. A non-paternal social-welfare function is one that reflects only the citizen's own evaluation of their happiness and wellbeing. A paternalistic social-welfare function can assess an individual's plight in a given situation differently than she would herself. In either case, the social-welfare function must impose some scheme for aggregating individuals' well-being. Should they simply be summed and, if so, in what units should they be measured? If summing seems inappropriate, what weights should be applied to different individuals and what is the implicit evaluation of inequality in outcomes?

The assumption that governments maximize a measure of social welfare has the advantage of flexibility. In principle, the social-welfare function can accommodate any considerations that the analyst deems appropriate, or descriptive of actual government behavior. The analyst need not take a stand a priori on what are valid concerns for members of society or how these concerns ought to be weighed or compared. Of course, in the application of this approach, the analyst adopts an objective function with particular arguments and so implicitly imposes restrictions on the validity and importance of alternative concerns. Unfortunately, there is little to guide the choice of the social-welfare function; essentially, the governments' objectives under this approach must come from outside the analysis.

A rather different approach to specifying the governments' objective function begins with an appreciation of political interactions. In this approach, the governments' objectives are induced by the political regime. Government officials, like private agents, are assumed to pursue their own well-being (or "utility") subject to constraints. Their utilities might reflect a taste for power or a pure desire to "do good," in addition to private concerns about material goods and perhaps the perquisites of office. After specifying the objectives of the political agents, the analyst must model the political interactions: What is the assumed electoral system? What are the voting rules, the political institutions, the role of campaign contributions, and the behavior of voters? Given the analyst's model of the political system, and the assumed interactions between political players, the government's objectives in its trade negotiations can be derived as a political outcome. 
That is, the electoral system, political institutions, and rules of the political game determine, among other things, the identities of the elected leaders and the policy positions they take.

This "political-economy" approach to government objectives recognizes, for example, that elected officials might pursue more strongly the interests of some constituents than others. The favored constituencies might be residents of swing districts, voters for whom trade policy is the most salient issue, or groups with ample resources to contribute to campaign financing. In any case, it is no longer clear, or even expected, that the government will pursue the aggregate and socially-just welfare of society.

The political-economy approach also has shortcomings. First, the approach relies on the modeling of political interactions. The more explicit are the government preferences used in the analysis, the sharper are the predictions about trade negotiations, but the more dependent are they on the plausibility and reliability of the assumed political model. Second, the induced government objective function need not be stable over time. Changes in the identities of the elected leaders may change the preferences of trade negotiators; changes in political institutions in the negotiating countries almost certainly will do so. This makes it difficult to render interpretations or predictions about trade agreements without detailed information about the state of politics in all the participating countries at the time of their discussions. Third, and perhaps most troubling, the composition of governments (and thus governments' preferences) may be jointly determined with the outcome of the trade negotiations. For example, some industries that only serve local markets prior to a trade liberalization may become exporters as a result of the trade agreement. If this changes the support in these industries for political parties, the formation of the trade agreement will influence government preferences. At the same time, government preferences obviously influence the formation of the trade agreement. In such circumstances, governments' preferences must be treated as endogenous, and predictions about the results of trade negotiations must be made jointly with predictions about political outcomes.

The different approaches to describing government objectives can be useful in different ways when interpreting the WTO Agreement. For instance, as mentioned above, Art. 31.1 of the Vienna Convention on the Law of Treaties holds that an agreement should be interpreted "in the light of its object and purpose." Matters of interpretation may therefore require us to consider what the negotiators were trying to achieve when drafting the agreement. Their intentions surely were conditioned on their actual politically-induced preferences, and not on some ethically-defensible preferences that they might have held in some best-of-all-possible worlds. Arguably, the political-economy approach is the more useful for illuminating such aspects. But the analyst may also want to take a stand on the 
objectives that the WTO ought to seek to achieve. The analyst would then follow the earlier mentioned approaches, by ascribing preferences that are his or her own, or that come from outside the analysis.

We will next introduce a formal (i.e., mathematical) tool that allows us to express certain ideas concerning government preferences in a compact fashion.

\subsection{A Formal Representation of Government Objectives ${ }^{6}$}

A basic tenant in virtually all economic analysis is that decisionmakers, such as consumers, producers, or governments, behave purposefully to promote their own interests - this is a loosely expressed version of the economic "rationality assumption."7 The mathematical representation of this idea rests on two key foundations.

First, it is assumed that the preferences of the decisionmaker fulfill certain properties; for example, a standard assumption is that if an option A is preferred to an option B, and B is preferred to an option $\mathrm{C}$, then $\mathrm{A}$ is also preferred to $\mathrm{C}$-this is the so-called transitivity property. It can be shown as a matter of mathematical logic, that if these basic assumptions are fulfilled, it is possible to represent the preferences of the decisionmaker by a mathematical function with certain properties - what in general terms is referred to as an "objective function" for the decisionmaker.

Second, it is commonly assumed that the decisionmaker will, when faced with a choice between several alternative policies and given the information available to him or her at the time, choose the option that best serves the objectives captured in the objective function. In what follows, the decisionmaker will typically be assumed to be a politician, and we thus assume that he or she chooses an option that maximizes the value of the objective function given informational and other constraints. This representation of the decision problem facing the decisionmaker is highly convenient from an analytical point of view, since it allows us to employ standard tools from optimization theory (the mathematical theory for how to find maxima and minima among sets of available alternatives) in order to shed light on the nature of policy choices.

In order to introduce a government welfare function to be used for trade-policy analysis, let us for simplicity (but without loss of generality) consider a world with two countriesHome and Foreign - and two goods. Each country's government will impose a tariff on its

\footnotetext{
${ }^{6}$ The content of this section is slightly more technical than the rest of the study.

${ }^{7}$ As a side point, it can be noted that this economic approach is commonplace in legal analysis, albeit in less strict form, for instance, when evaluating motives and intent.
} 
imports at some rate, denoted $t$ for the Home government, and $t^{*}$ for the Foreign government. ${ }^{8}$ Also, let the symbol $G$ denote the Home government's objective function. This function describes how different constellations of tariffs affect the government's perceived utility - that is, how the government evaluates the various outcomes that result. To express the dependence of the value of objective function on the tariffs that are chosen, we write this as $G\left(t, t^{*}\right)$, spelled out as " $G$ is a function of the tariffs $t$ and $t^{*}$." Note that the government's assessment of its well-being depends not only on its own tariff rate, but also on that of the other country, reflecting the interdependence between the two governments.

The function $G\left(t, t^{*}\right)$ is clearly a very abstract way of expressing the dependence of government well-being on the tariffs: we have not yet mentioned anything about how the tariffs affect the governments. This influence will most likely depend on a number of considerations, such as the how the tariffs will affect economic variables such as trade volumes, incomes, consumption levels, employment, etc. It will also depend on how the political system rewards the government for different economic outcomes, and how the decisionmakers in the government evaluate these political rewards. All these aspects of how the tariffs affect the decisionmaker are conveniently packaged into the symbol $G$. In Section 4 we will open this black box, and consider what may lie behind this general but abstract representation of the economic-cum-political system. However, in order to avoid losing sight of the broader picture, we will first employ the more general formulation. Accordingly, our analysis in Section 3 lacks institutional detail and makes only a few relatively unobjectionable assumptions about the properties of the government welfare function $G\left(t, t^{*}\right)$.

\subsection{Predicting Outcomes of Strategic Interaction}

In the setting we have just sketched, the Home government maximizes the value of the function $G\left(t, t^{*}\right)$ and the Foreign government, we assume, seeks to maximize an analogous objective function $G^{*}\left(t, t^{*}\right)$ that reflects the economics and politics abroad. What tariffs would result from these partly conflicting ambitions in the absence of any explicit trade agreement?

This is an example of a much more general question, concerning the outcome of strategic interactions in the absence of binding contracts. Mathematicians and social scientists have developed the tools of "non-cooperative game theory" to predict the outcomes of such interactions, and this body of theory is drawn upon in all fields of economic analysis to

\footnotetext{
8 We use the symbol "* " to denote a variable or a function pertaining to the Foreign country.
} 
predict the outcome of strategic interaction. This theory provides the benchmark that is used in the literature on trade agreements to explain the reasons for trade negotiations and to evaluate their success. In particular, we adopt as our benchmark the basic concept from non-cooperative game theory, the "Nash equilibrium" of a "simultaneous-move, one-shot game"-a concept that we will describe in what follows.

In this formulation, the two governments are assumed to choose from a set of feasible interventions, in this case all possible import tariff rates. Each government makes a onceand-for-all choice of policy without knowing what policy the other will choose, but recognizing the incentives that the other faces. The two policies are announced simultaneously, each selected in anticipation of the other. The Nash equilibrium is the most widely-used concept for predicting outcomes of noncooperative games; and although much has been written about its applicability in particular settings, it remains an accepted and useful starting point for the analysis of strategic interaction.

The assumption that policy choices are made simultaneously is meant to cast the players in a symmetric position with regard to timing. By this assumption, no government has the opportunity to commit to its policies before the others can act, nor can any government wait to observe its rivals' final choices before making its own decisions. This seems appropriate in our benchmark setting, because in the absence of an international agreement, governments might find it difficult to bind their policies in a way that could not subsequently be changed, and there is no natural sequence of tariff setting to be assumed.

The assumption that policies are set once and for all requires more explanation. Formally, this means that the game is solved as if the governments do not contemplate the possibility of future policy changes. Needless to say, this assumption is unrealistic and by invoking it we may be imparting undue pessimism about what the trading environment would be like without a negotiated agreement. We have several reasons for using the oneshot game as our no-agreement benchmark. First, the assumption of a single interaction delivers a simple analysis that is easy to understand, whereas dynamic games with repeated (or sequenced) interactions are much more complex. Second, if we were instead to assume that governments set policies in an indefinitely repeated sequence of periods, we would find that one possible Nash equilibrium outcome of this interaction is the indefinite repetition of the strategies invoked in the equilibrium of a one-shot game. That is, if all players realize that the game will be played repeatedly but all expect the others to act as if they are only concerned with their short-run (one-shot) interests, then no one will have any reason to behave differently from what it would do in a single play of the game. In this sense, our benchmark survives as a sensible equilibrium outcome even in a setting that allows for repeated interaction. Finally, the equilibria of the repeated game besides 
the one that has indefinite repetition of behavior in the one-shot game, all involve "tacit cooperation." Although the players are assumed to choose their actions independently, without consultation and without direct concern for the impact on others, they behave in these equilibria as if they were cooperating, because each believes that rivals will punish a selfish act today with retaliation tomorrow. Indeed, the structure of modern trade agreements shares many features with the tacitly-cooperative equilibria of a repeated game. As will be discussed further in Section 3.4.2, in both the WTO Agreement and the theoretical construct of a Nash equilibrium with tacit cooperation, there can be no legal enforcement of "good" behavior by an outside party. Both the actual agreement and the theoretical construct rely instead on internal enforcement, with bad behavior deterred by threats of retaliation and punishment. Since trade agreements mirror in many ways the game theorist's predictions about equilibria of repeated games with tacit cooperation, we choose to treat the outcome of a repeated game not as our no-agreement benchmark, but rather as informative about what might result from bargaining. ${ }^{9}$

Before leaving this section, we introduce one further bit of game-theory terminology, which is that of a "best response." A player's best response to an action by his rival is a choice for his own action that best serves his interests given the action of the other player. A "best response function" identifies a player's best response to every possible action that his rival might take. A Nash equilibrium of a simultaneous-move, one-shot game can be characterized using the players' best response functions; specifically, it is the point at which the two functions intersect. In a Nash equilibrium, if player 1 takes action $a$ and player 2 takes action $b$, then $a$ must be a best response for player 1 to the action $b$ by player 2 , while $b$ is a best response for player 2 to the action $a$ by player 1 . With mutual best responses, each player anticipates its rivals' behavior and each responds optimally in light of those expectations. Hence, in Nash equilibrium, no player is surprised by a rival's actual play and no one has any reason to alter behavior once rivals' actual actions are revealed.

\section{A General International Externalities Model of Trade Agreements}

This section introduces a general model of how international externalities that result from unilateral policy setting may create a useful role for trade agreements. We intentionally present the model at a high level of abstraction, in order that details about government preferences, political institutions, and other aspects of the environment do not conceal the

9 We will discuss the related issue concerning the similarities and differences between explicit agreements and tacit cooperation below. 
underlying nature of the strategic interactions between governments. A more detailed, but therefore also more narrow, model will be presented in Section 4 .

In order to assess the purpose of a trade agreement, we first need to specify government objectives. We do so in Section 3.1, where we make a few assumptions concerning the properties of the welfare function $G\left(t, t^{*}\right)$ we introduced in Section 2.3. Second, using the concept of the Nash equilibrium that we described in Section 2.4, Section 3.2 defines the benchmark policies that we would expect to see in the absence of any negotiation and cooperation. Section 3.3 then adopts the notion of Pareto efficiency for the two governments as a means to predict the outcome of a trade negotiation and to gauge the performance of a given agreement. That is, we assume that the outcome of the negotiation fulfills two properties: first, all parties gain from the outcome relative to how they would fare in the benchmark situation, which we take to be the (one-shot) Nash equilibrium; and second, no alternative policies can be found that would benefit one government and not harm the other. In some circumstances (that we shall describe), bargaining may be expected to yield just such an outcome. We emphasize that the predicted gains from an efficient agreement are measured relative to the objectives of the negotiators, with whatever preferences they may hold and whatever interests they may represent. An efficient agreement need not benefit all residents of a country, or even a majority of such residents. ${ }^{10}$ In Section 3.4, we will point to several practical considerations that may limit the scope for achieving a fully efficient agreement, and we will point out how these practicalities might influence the design of a trade agreement.

\subsection{Imposing Minimal Structure on Government Objectives}

We now need to be a bit more specific about the governments' preferences as they enter into international negotiations. We suppose, as we mentioned before, that the Home government's preferences can be represented by a (government) welfare function $G\left(t, t^{*}\right)$. But now we also assume that this function has some specific properties: ${ }^{11}$

1. Starting from a Home tariff of zero, the Home government's welfare rises when a (small) positive Home tariff is introduced. ${ }^{12}$

${ }^{10}$ Although much of the approach that we shall develop here would be applicable to any multilateral agreement, we shall limit our focus to the study of "trade agreements." Narrowly defined, such an agreement directly constrains governments' choices of policies to promote, impede, or regulate the flows of goods and services across borders. A broader definition would include constraints on policies that govern other cross-border flows, such as those of capital and technologies.

11 Some additional, necessary assumptions are left out, being of a more technical nature.

12 More formally, $G\left(t, t^{*}\right)$ is an increasing function of $t$ when evaluated at $t=0$ and any value of $t^{*}$. 
2. As the Home tariff is increased holding the Foreign tariff rate constant, the Home government's welfare eventually reaches a peak and then declines. ${ }^{13}$

3. The welfare of the Home government falls whenever the Foreign tariff is increased. ${ }^{14}$

The first property implies that the Home government always has a unilateral incentive to impose some positive tariff. The second ensures that the benchmark tariff is not prohibitive, which certainly seems in line with real-world observations. The final property embodies the international externality; it says that the Home government is harmed by protection abroad.

The Foreign government preferences $G^{*}\left(t, t^{*}\right)$, have the same properties, but with the roles of the tariffs being reversed. The Foreign government benefits from some positive tariffs $t^{*}$, but it suffers from any increase in the Home tariff, $t$.

\subsection{The Benchmark Outcome: Unilateral Policy Decisions}

In Figure 1, point $A$ represents the Home government's best response to the foreign tariff $t_{A}^{*}$. That is, if the government of Foreign were to set its tariff rate at $t_{A}^{*}$, the Home government would maximize its own objective function by setting the Home tariff equal to $t_{A}$. The Home government might prefer this positive tariff for any one of a number of reasons - the very general formulation of the government objective function allows for a range of different interpretations, as will be seen. But in this section, the reason why governments prefer to invoke trade barriers is not important.

${ }^{13}$ This assumption is not needed for the main points that we shall make, it ensures that the benchmark tariffs are not prohibitive, which seems realistic.

${ }^{14}$ More formally, $G\left(t, t^{*}\right)$ is a decreasing function of $t^{*}$ for any value of $t$. 


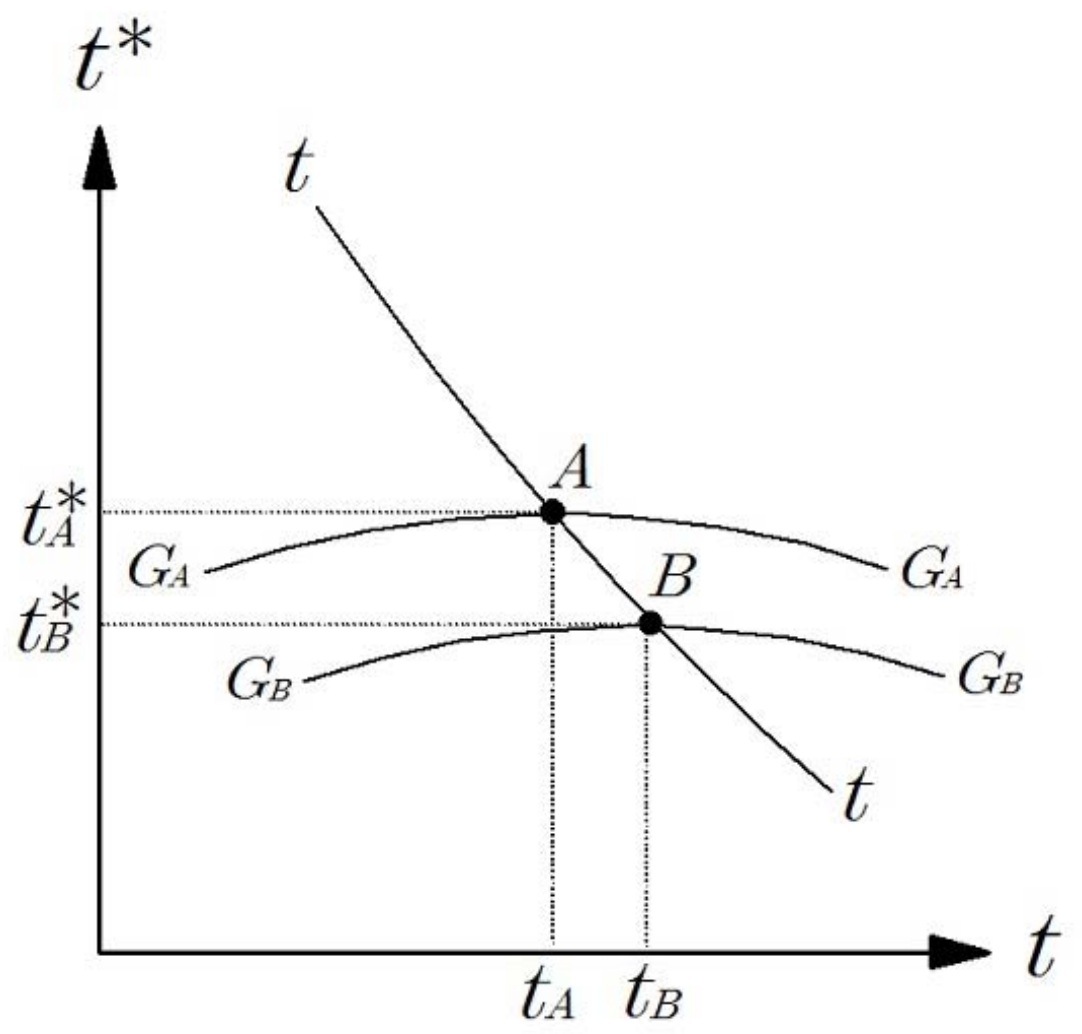

Figure 1: Best Response

Notice the curve $G_{A} G_{A}$. This curve depicts all combinations of $t$ and $t^{*}$ that generate the same level of utility for the Home government as at point $A$. A point directly to the right of point $A$ (which is not on the curve) yields less utility to the Home government than does point $A$, because $t_{A}$ is the best response to $t_{A}^{*}$ and so any other response must be inferior to it. A point to the southeast of $A$ could, however, yield the same level of welfare to the Home government as point $A$, because the loss associated with moving to the right from point $A$ is compensated by a gain from moving $t^{*}$ downward. The latter movement reflects a reduction in the foreign tariff for a given home tariff and could benefit the Home government by providing improved access to the foreign market for domestic producers. Similarly, a point directly to the left of point $A$ could not yield as great a value for $G\left(t, t^{*}\right)$ as point $A$, but a point to the southwest of $A$ could do so by compensating the loss from a leftward move with a gain from a downward move.

The Figure also shows point $B$, which is the Home government's best response to a foreign tariff of $t_{B}^{*}$. The curve $G_{B} G_{B}$ depicts combinations of the two tariff rates that deliver the same level of utility to the Home government as it achieves at point $B$. We could 
indicate other points like $A$ and $B$, and other curves of constant government utility that pass through these points. By connecting points $A, B$, and the others like them, we trace out the curve $t t$, which represents the aforementioned Home best response function; i.e., the optimal policy choices for the Home government in response to every possible value of the Foreign tariff. We have drawn the curve as downward sloping, because many economic and political-economic models suggest that the optimal home tariff shrinks as the foreign tariff grows. ${ }^{15}$ But the slope of the curve is not important at this point.

In Figure 2, we have reproduced $t t$ and $G_{B} G_{B}$. We have also drawn $t^{*} t^{*}$, which depicts the Foreign best response function; i.e., the optimal policy for the Foreign government in response to every tariff $t$ that the Home government might set. This curve is derived by an analogous thought experiment to that which gave us $t t$. The curve $G_{B}^{*} G_{B}^{*}$ represents the combinations of $t^{*}$ and $t$ that yield the same level of political utility to the Foreign government as it would obtain with the combination of tariffs $t_{B}^{*}$ and $t_{B}$. Its derivation mirrors that of $G_{B} G_{B}$ but uses instead the Foreign government's preferences, $G^{*}\left(t^{*}, t\right)$.

Now, at last, we are ready to identify the Nash equilibrium, which is found at point $B$. This pair of policies has the property that $t_{B}$ is a best response by the Home government to $t_{B}^{*}$ while $t_{B}^{*}$ also is a best response by the Foreign government to $t_{B}$. With these choices, neither government has any reason to alter unilaterally its tariff rate. If the Home government expects the Foreign government to set $t_{B}^{*}$, its best policy response is $t_{B}$. If the Foreign government expects $t_{B}$, its best response is $t_{B}^{*}$. We consider this Nash equilibrium to be the benchmark outcome that would arise in the absence of cooperation between the two governments. Although our artistic abilities (and geometry) limit us to two dimensions in the figures, the idea of a Nash equilibrium would be the same with any number of goods, any number of governments, and any number of policy instruments at their disposal.

15 This could be, for example, because a higher foreign tariff shrinks the overall volume of trade and so reduces the political gains available to the Home government from providing protection. 


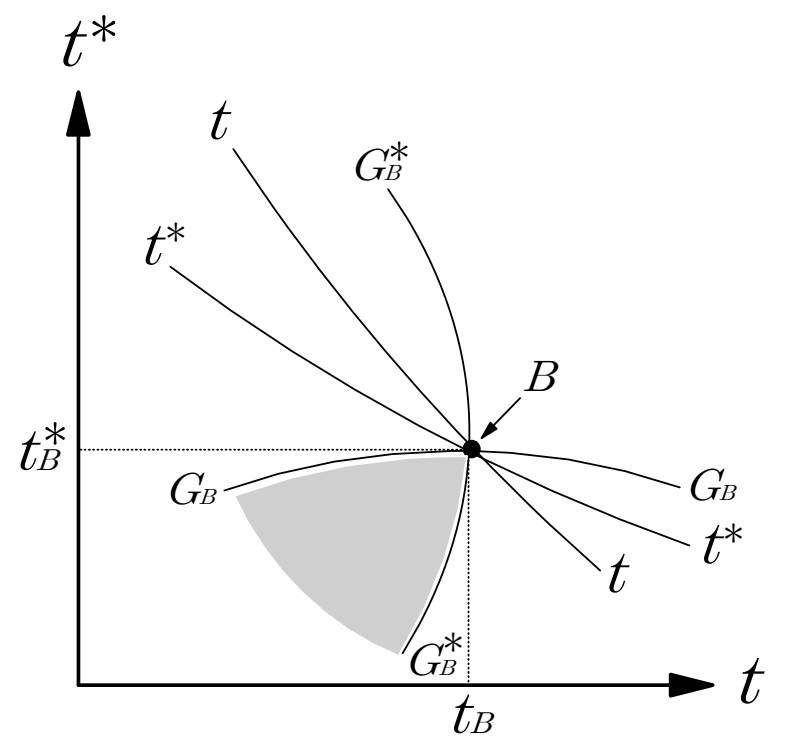

Figure 2: The Nash Equilibrium

The features of the Nash equilibrium can help us to understand some of the language that is used to describe trade negotiations. In a negotiation, governments are asked to make concessions to their trade partners. These are concessions, because any unilateral change in policy harms a government that has chosen a best response. For example, the Home government loses political welfare by moving horizontally from its best response curve $t$. Governments might concede in this way only when they anticipate reciprocity from their partners. Whereas a movement due left from point $B$ cannot benefit the Home government, a movement to the southwest conceivably could do so, if the political benefits from a reduced foreign tariff compensate the perceived loss from a lowering of Home barriers. The shaded area in Figure 2 illustrates such mutually beneficial, reciprocal liberalization.

\subsection{An Efficient Trade Agreement}

Starting from the benchmark situation that is depicted in Figure 2, the Home government and the Foreign government have clear reasons to negotiate. As the figure shows, the curve $G_{B} G_{B}$ has a horizontal slope at point $B$, whereas the curve $G_{B}^{*} G_{B}^{*}$ has a vertical slope 
at this point. ${ }^{16}$ The fact that the two curves are perpendicular at $B$ reveals an opportunity for mutual gain. Consider the policy combinations represented by points in the shaded region. These points lie below the curve $G_{B} G_{B}$ and so correspond to greater political welfare than at $B$ for the Home government, and they lie to the left of $G_{B}^{*} G_{B}^{*}$ and so correspond to greater political welfare than at $B$ for the Foreign government. If the governments can agree to choose policies from the shaded region, and if that agreement can be enforced, then each government stands to reap political rewards.

Why must there be scope for mutual gain? We shall address this question more fully beginning in Section 4, where we will describe in more detail the functioning of the underlying economy and government preferences, but the intuition can be explained now. When the Home government chooses its best response to $t_{B}^{*}$ at point $B$, it neglects the spillover effect that its policy choice has on the welfare of the Foreign government. A small change in the Home tariff would reduce the Home government's welfare only slightly (because a near-optimal choice yields almost the same welfare as an optimal choice), but would provide clear political gains to the Foreign government. ${ }^{17}$ Similarly, $t_{B}^{*}$ has been chosen by the Foreign government to maximize its own objective function without regard to the adverse impact on the Home government. The Foreign government too can alter $t_{B}^{*}$ at relatively little cost to itself and generate a non-negligible gain for its counterpart. By agreeing to reduce tariffs from $t_{B}$ and $t_{B}^{*}$ to some pair in the shaded region, the two governments can achieve mutual gains in political welfare.

Figure 3 illustrates an efficient outcome from the perspective of the Home and Foreign governments. At point $E$, with policies $t_{E}$ and $t_{E}^{*}$, the curves $G_{E}$ and $G_{E}^{*}$ are tangent to one another. An improvement in the Home government's welfare relative to point $E$ requires movement into the horizontally-shaded region, whereas an improvement in the Foreign government's welfare relative to point $E$ requires movement into the vertically-shaded region. As is clear from the figure, there are no combinations of $t$ and $t^{*}$ that lie in both of these regions; thus, there does not exist a feasible policy change relative to point $E$ that benefits one government without harming the other-this pair of tariffs is thus Pareto efficient.

16 The horizontal slope of $G_{B} G_{B}$ at $B$ is a consequence of maximization by the Home government. It anticipates the foreign policy $G_{B}^{*}$ and chooses $t$ to reach the highest (i.e., southernmost) welfare contour. The vertical slope of $G_{B}^{*} G_{B}^{*}$ has a similar explanation.

${ }_{17}$ In many political and economic models, the Home government must gain from a reduction in the foreign tariff, as we discuss further below. However, our argument that both governments can gain from an agreement is more general than this, and applies whenever the no-agreement benchmark is the one-shot Nash equilibrium. 


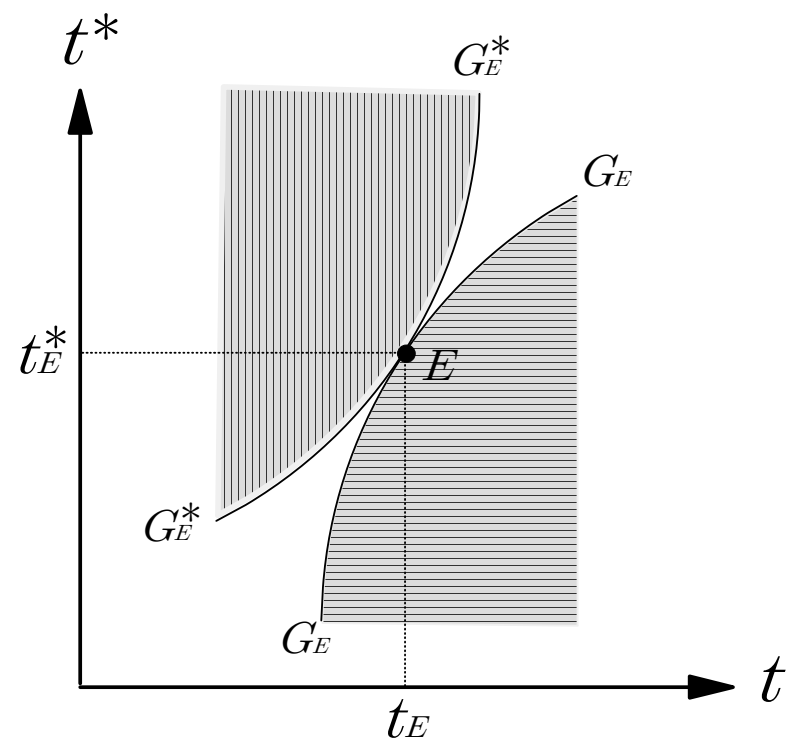

Figure 3: The Efficient Agreement

It is important to stress the nature of the efficiency that is at issue here. The efficiency depicted in Figure 3 is defined in relation to the governments' objectives, as it is the government officials who conduct trade negotiations. If a negotiated trade agreement were to prescribe the policies associated with point $E$, neither of the negotiators could offer a proposal that its government prefers to $E$ that would be acceptable to his counterpart. But, as we discussed in Section 2.2 the preferences of government officials are colored by the political environment in which they operate and need not coincide with measures of social welfare. So, it is impossible to say without further information about the politics in each country whether an agreement at point $E$ best serves the citizens of the two countries, or even whether such an agreement raises aggregate welfare (somehow measured) relative to what it would be without any trade agreement.

\subsection{The Design of Trade Agreements}

In Section 3.3 we explained why unilateral policymaking in interdependent countries is likely to result in inefficient policies. We have shown why the governments have an incentive to cooperate, and we have identified the conditions that would need to be satisfied by a fully efficient agreement. But we have not talked about how negotiators might go about generating political welfare gains relative to the benchmark outcome, nor about whether a potential agreement would be sustainable and enforceable. Moreover, we have oversimplified the world by pretending that there are only two parties to the 
negotiation, that there are only two tariff rates to be discussed, that the parties' preferences are clear-cut and stable, that each side's preferences are fully known by the other, and so on. In this section, we outline some of the issues that a theory of trade agreements must overcome in moving from an explanation of why trade agreements might exist to an explanation of what form they take and what their myriad provisions are meant to achieve.

\subsubsection{Trade Agreements Are Negotiated}

A salient feature of trade agreements is that they result from explicit negotiations. These negotiations make each party sensitive to the externalities that result from its existing policies. If the Home and Foreign governments negotiate about their respective policies measures $X$ and $Y$, government $B$ might offer to change policy $Y$ by a certain amount in exchange for a certain change in policy $X$ by government $A$. The latter can opt to continue to pursue its original level of policy $X$, but now it must bear a cost for doing so in terms of the foregone "concession" from its counterpart. Through the process of offers and counteroffers, negotiations can induce the parties to internalize the externalities that their unilateral choices impose.

But what policies will emerge from such a process? Here, the economic literature is less clear. Even if the parties are fully aware of the preferences of their counterparts, there are many policy combinations that are Pareto efficient. Some combinations give greater welfare to government $\mathrm{A}$ at the expense of government $\mathrm{B}$, while others do the opposite. The economics literature on bargaining explains how the outcome will depend on a number of considerations, such as the well-being of the two parties in the status quo, who has the chance to make the first offer, the bargaining protocol that is used, and the patience of the parties to the negotiation. Although there are elegant theories to predict the outcome of a negotiation carried out with full information, these theories rely on strong assumptions about exactly how the bargaining takes place; e.g., that offers must alternate between the parties and that a fixed amount of time must pass between offers.

More worrisome, still, is the assumption of full information and common knowledge. Governments cannot easily know the political pressures that their counterparts face or exact meaning of these pressures in a foreign context. As a result, they typically enter negotiations with uncertainty about the counterparts' preferences, as well as uncertainty about how different policies will affect the economy and their own political well-being. In the face of uncertainty and imperfect information, it becomes much more difficult if not impossible to achieve an efficient outcome of the sort described above. 
Imperfect information gives parties an incentive to posture and bluff in the hope of convincing negotiating partners that the cost of changing one's own policies is high or that the prospective benefit that will come from the other's concessions is small. In such an environment, it is no longer obvious that the parties will accept any offers that improve their conditions relative to the status quo. It may be optimal to decline an attractive offer in the hope of generating one later that is even better.

The history of GATT and WTO negotiations suggests that such considerations are important in the world of international trade policy. Trade negotiations are notoriously slow and seemingly are becoming more so over time. Indeed, the current negotiations in the Doha Round have been so much delayed by intransigence from many parties that it seems possible that cooperation will not be achieved.

Unfortunately, models with complete information cannot explain why negotiations take time; delays only postpone the realization of the gains from the cooperation. Models of bargaining with imperfect information may explain why it takes time to conclude an agreement, or even why a negotiation ends without an agreement even if both sides know that there are potential gains from cooperation. Most theories of trade agreements nevertheless assume that the parties have full information, for two related reasons. First, models of bargaining under imperfect information are typically too complex to be useful as tools for analyzing the structure and implication of trade agreements. Second, predictions from these models are often extremely sensitive to what might seem to be somewhat arbitrary details of how the negotiations are conducted.

\subsubsection{Trade Agreements Must Be Self-Enforcing}

Were it not for informational problems just described, the idea of an efficient agreement might seem very compelling. Why would the parties end a negotiation and sign on to an agreement if they realized that further mutual gains were still possible? Why wouldn't some party make a further proposal if policy combinations exist that would be better for itself and also better for its counterpart? How could an outcome with ongoing inefficiency be sustained?

The literature on trade agreements offers some unsettling answers to these questions that point to the difficulty of enforcing international trade agreements. In other negotiating contexts, agreements are enforced by third parties. When private parties enter into a legal agreement, they can count on the government to enforce the terms of the contract. Then, if one side feels that the other has not fulfilled its obligations, it can sue for damages in a court of law. Once a judgment has been obtained, the aggrieved party can further rely on 
the police to ensure that the court's stipulated restitutions are carried out. But trade agreements are inevitably contracts between sovereign entities. There is no disinterested third party to enforce these agreements and no international police to ensure that damages are paid. Trade agreements can survive only if the parties choose to honor their terms on an ongoing, and essentially voluntary, basis.

Why should there be any need for enforcement of an agreement that all parties sign and from which all parties presumably reap benefits? Recall from Section 3.3 that whereas the noncooperative choices depicted in the Nash equilibrium of Figure 2 lie on the governments' respective best response functions, the efficient policy choices identified in Figure 3 do not. Indeed, by definition, the Nash equilibrium policies are the ones that leave neither party with an incentive to change behavior unilaterally. For all other policies, and especially for the efficient policies, the parties must be behaving in such a way that they do not maximize their own utility for the actions prescribed for the other. But this means, of course, that all parties to an agreement will want to "cheat," if they think they can get away with it. Starting from a point such as $E$ in Figure 3, the Home government could benefit by raising its tariff $t$ while the Foreign government sticks to a policy of $t^{*}$, and the Foreign government would benefit by increasing $t^{*}$ while the Home tariff remains with $t_{E}$.

But could they get away with it? If the only policies at issue were border tariffs, then presumably they could not do so for long. The tariffs collected by a customs authority are apparent to the foreign firms that must pay them, which could almost immediately report on violations of the terms of any agreement to their national government. But governments have more ways to provide protection than only with tariffs. They often can replicate the effects of such policies, or at least nearly so, with combinations of other fiscal instruments, with quantitative restrictions, and with administrative and other impediments to trade. A violation of the terms of a trade agreement may not be as transparent and as readily observable as would be the levying of an excessive tariff charge. Some forms of cheating might go undetected for a long time and others might occur in ways that require careful and subtle investigation in order to determine whether they constitute an abrogation of the agreement or not. Considering the difficulties that are likely to arise in monitoring and detecting actions that run counter to a trade agreement, our theories of such agreements should recognize that the parties have incentives to cheat and often will have opportunities and means to do so.

The literature on trade agreements has sought to address such concerns about enforcement by looking for outcomes that satisfy a "self-enforcement" constraint. An agreement is self enforcing if the parties prefer to take the actions stipulated by the agreement to all other options open to them, considering both the likelihood that they 
would be "caught" behaving differently, the expected time until "detection" of such behavior, and the consequences that would ensue.

The literature on "repeated games" can guide us in understanding the implications of the self-enforcement constraint. Repeated games are strategic interactions that recur in the same form over time. In the trade-policy context, for example, we might consider the repeated game in which two governments repeatedly set tariff rates for their import goods for some period of time. At the beginning of each period, the governments would simultaneously choose the tariffs (or other similar, but less observable policies) that would apply during the period. A period in this context is the time it would take before a party would recognize a change in its rival's behavior and change its own behavior in response. The theory of repeated games has asked how much cooperation can be sustained in the Nash equilibrium of such repeated play, considering that some opportunistic actions by each party would be deterred by the threat of later retaliation by the other. The threat of retaliation means that-even in the absence of a formal agreement or contract-it may be possible to sustain more cooperative behavior than the Nash equilibrium of the one-shot game. In a repeated equilibrium with cooperation, each party refrains from pursuing its (short-run) best response to the other's action, expecting that its counterparts will do likewise. Each (implicitly) threatens to punish any opportunistic behavior by its counterparts, and each expects that any of its own opportunistic actions will invoke similar retribution by the others. Punishments must be credible in the sense that it must actually be in the interest of each party to carry out what is expected of it should some violation of the implicit agreement actually occur. By construction, the equilibrium outcomes of repeated games are self enforcing, because they require no adjudication and penalties imposed by disinterested third parties.

So, how much cooperation can be sustained by threat of punishment in repeated play? The answer depends on a number of features of the strategic environment, including the time it takes for detection of opportunistic behavior and the response to it, the size of the gains that each player can capture by cheating until detection, and how much each player would give up by forgoing some subsequent cooperation. But, however much cooperation might be possible in such a setting, the theory does not predict a unique outcome for the repeated play. ${ }^{18}$ The theory does predict, however, that the more patient are the parties (i.e., the less they discount events in the future), the higher the maximal degree of cooperation that can be sustained. In particular, the self-enforcement constraint

18 There is a path of play sustained by players' beliefs about what is expected of them and by credible punishments for departures from expected behavior that achieves "the most cooperative equilibrium," as well as many other paths that involve lesser standards of good behavior and that achieve less (but still some) cooperation. 
is likely to prevent the parties from reaching a fully efficient outcome, such as the one identified by point $E$ in Figure 3, since it would be too tempting for any government to cheat on such an agreement. Since there are reasons to believe that governments are typically rather short-sighted, we should indeed expect the best outcome to involve much higher tariffs than what would be fully efficient.

\subsubsection{Trade Agreements Are Explicit and Incomplete}

The two-countries, two-product framework illustrates starkly the basic gains from an arrangement that takes the parties from an inefficient unilateral outcome, toward the efficiency frontier. But the simplicity of the analysis is deceptive, in that it appears so simple for the parties both to identify more efficient outcomes, and to maintain such outcomes through repeated interaction. In practice, the problem of designing an agreement is enormously complex: the agreement needs to cover not just two countries and two products, but many countries, and millions of goods; there are international externalities not only from trade instruments, but from a huge number of domestic policy instruments; the economic environment is highly uncertain, being bombarded by changes in the underlying conditions such as changes in technology, natural resources, tastes, weather, politics, etc. This complexity has profound implications for the design of the agreement.

A first implication is that it is necessary to come to an explicit agreement on the terms for the cooperation. It seems highly unlikely that the cooperation that has been implemented through the creation of the GATT/WTO could have been achieved if Members had not explicitly agreed on how to cooperate though a series of negotiation rounds, and through innumerous meetings between rounds. The reader might view this as a rather trivial observation - but it is actually an aspect of trade agreements that economics has difficulty explaining. As described above, theory shows how governments in a repeated interaction can benefit from refraining from short-run, opportunistic behavior if they believe such actions would induce other governments to retaliate in kind. But "all" this theory says is that a certain set of behaviors jointly support a Nash equilibrium that is more efficient than the one-shot Nash equilibrium. The theory is silent on how the parties can coordinate their expectations concerning what is, and what is not, accepted as cooperative behavior. But it can be imagined that a trade agreement makes explicit what would only be implicit in a tacitly-cooperative equilibrium of a repeated trade-policy game. The agreement could spell out the behavior that is expected of governments in the pursuit of cooperation and the retaliation that should ensue from opportunistic behavior. In so doing, it could coordinate expectations and help to implement one of the cooperative outcomes among those that are sustainable under repeated play. And so long as the 
agreement stipulates actions that would themselves be sustainable as an equilibrium outcome of a repeated game without a formal contract, it will not require any external enforcement. By taking this perspective, we again cast doubt on the feasibility of a fully efficient outcome, such as the one identified by point $E$ in Figure 3.

Second and related, the complexity of the interaction implies that an explicit agreement between the parties would have to be an extraordinarily lengthy document, if it were to identify a fully efficient outcome. Such an agreement would have to dictate the legitimate uses of a myriad of domestic policy instruments, and it would have to be sensitive to changes in an incalculable number of economic and political conditions. The construction of such an agreement is, of course, a practical impossibility because of the time and administrative costs it would require, if at all possible. As a consequence, trade agreements are by necessity incomplete in various ways. ${ }^{19}$ First, contractual bindings are less responsive to changes in the underlying economic and political environment than they should ideally be; for instance, tariff bindings are not conditioned on such changes except for through the means of escape mentioned above. Second, the agreement does not bind all policy instruments, but leaves discretion over certain policies to the parties; for instance, the GATT leaves discretion over domestic instruments to the Members, albeit with certain constraints imposed. Third, contractual provisions are expressed vaguely in order to save negotiators time.

The incompleteness of the agreement provides yet another reason why the parties cannot achieve a fully efficient outcome. It also has the important implication that the agreement would benefit from the inclusion of a dispute-settlement mechanism, since it will often be unclear whether undertaken measures should be seen as violating the agreement, and the parties need to agree beforehand on how to resolve such conflicts. Hence, the need for interpretation of the agreements largely stems from this incompleteness. The "contractual incompleteness" of trade agreements will be discussed in more detail in the accompanying ALI study on the treatment of domestic instruments in the GATT.

19 We here emphasize the role of contracting costs for contractual incompleteness. The economic literature points to two further reasons for incompleteness, both of which seem important for the design of the GATT: first, some aspects of the state of the world may be unverifiable by a court, and so contracts that included contingencies under such states of the world could not be enforced; and second, some aspects of the state of the world may be unforeseeable or not possible to describe, making it impossible to include these in the contract. 


\subsubsection{Trade Agreements Involve Reciprocal Exchanges of Concessions}

The final property of the design of trade agreements that we will point to is that they entail reciprocal reductions in tariffs, and other trade barriers. In theory, it would be possible to have nonreciprocal agreements. Indeed, each pair of countries could negotiate a separate agreement for each tariff line and for each trade direction, with each such agreement specifying a tariff reduction against, say, a monetary payment. The fact that virtually all agreements we observe involve reciprocal undertakings to reduce trade barriers, strongly suggests that there are efficiency gains from reciprocal exchanges that are not captured in the model above. The economic literature offers surprisingly little by way of explanation of this feature, however. But it seems quite clear intuitively that it would be extremely costly to negotiate separate agreements for each trade barrier, since this would involve significant duplication of negotiation efforts and other resources; for instance, each of the agreements would then require a separate dispute-settlement mechanism. Furthermore, the payments require the collection of tax revenue, which is likely to distort the economy. In addition, the parties need to agree on the monetary value of each tariff concession, which might be more difficult than to agree on reciprocal tariff reductions. There are thus clear gains in terms of reduced administrative costs and negotiation costs to form a package of tariff reductions.

\section{A Special Case: The National Market Power Model}

The effects of government's economic policies cross international boundaries and impact actors residing outside their political borders. In the previous section, we argued that the threat of such policy externalities provides a strong motivation for governments to participate in international trade agreements. To analyze the impact, we assumed that governments' decisionmaking with regard to trade policy could be represented as maximizations of the welfare functions $G\left(t, t^{*}\right)$ and $G^{*}\left(t, t^{*}\right)$. We made some intuitively plausible assumptions concerning the properties of these functions, illustrated in Figure 3 , but we did not specify any details concerning what more specifically lay behind this function. With this very general framework, we illustrated the gains that could be had from a trade agreement. On the one hand, this shows the generality of the proposition that trade agreements solve problems arising from international externalities, since it is highly plausible that countries will affect each other in the assumed manner through their trade policies. On the other hand, one may wonder what underlying situations fit this description. 
Most economic analysis of trade agreements are conducted in international externality frameworks with more detailed institutional structure imposed than in the general model above. Institutional details are typically added in two respects:

- a description of how tariffs affect economic outcomes, such as trade volumes, incomes, consumption levels, employment, wages, etc. These relationships are embedded in a model of the economy; and

- a description of how governments rank and choose among these different economic outcomes.

In what follows we will discuss the standard approach to model the role of trade agreements. As will be argued, this approach is broad enough to allow for many different treatments of the above two points. But the approach is defined by the assumption that governments have incentives to exploit their ability to extract surplus from trading partners by restricting imports, and that this causes an international inefficiency. Because of the close parallel with the behavior of firms with market power, we will denote this as the "national market power" approach. Section 4.1 will lay out the unilateral incentives for governments to employ tariffs in order to exploit national market power. The structure of the analysis will ultimately be the same as in Section 3.2, but we now go behind the general expressions $G\left(t, t^{*}\right)$ and $G^{*}\left(t, t^{*}\right)$, by making detailed assumptions concerning the structure of the economy and government behavior. The rest of the section then discusses the theoretical generality and practical relevance of the approach.

\subsection{When Free Trade Is Unilaterally Optimal}

A theory of trade agreements requires an explanation for why countries would restrict trade if they were not bound by any treaty. A trade agreement would be unnecessary if free trade were in the unilateral interests of all countries. Trade economists have identified circumstances in which all governments would opt for free trade without needing any explicit agreement. In particular, a government will unilaterally choose free trade when:

1. all markets are perfectly competitive;

2. production occurs under constant or decreasing returns to scale;

3. there are no externalities;

4. the country as a whole does not affect the prices at which it trades internationally; and

5. the government pursues an objective of maximizing national income (or social welfare). 
When these five assumptions are satisfied for both countries, the government welfare functions $G\left(t, t^{*}\right)$ and $G^{*}\left(t, t^{*}\right)$ have the property that $t=0$ is a best response to any tariff $t^{*}$ chosen by the foreign government and that $t^{*}=0$ is a best response to any tariff $t$ chosen by the home government. The Nash equilibrium in the absence of any trade agreement is characterized by universal free trade.

The standard approach to trade agreements may incorporate departures from several of these assumptions. Most importantly, however, all models that take this approach dispense with Assumption 4, which is known in the literature as the "small country assumption." This assumption stipulates that a country can set its national policies without any spillover effects on its trading partners. If a country were so small that its national policies had no international ramifications, then indeed there would be no need for the world trading system to restrict its actions in order to achieve global efficiency. But most countries are large enough to affect world prices in at least some markets. As we shall see, zero tariffs would not be a unilateral best response for such moderately-sized or larger countries, even if their governments took the maximization of social welfare as their objective. We will follow the literature in assuming that each country's policy choices affect at least some world prices and turn now to a closer examination of what incentives such countries have to restrict trade in such circumstances.

\subsection{The Unilateral Incentive to Exploit National Market Power}

Economists have long recognized that governments concerned with national income may have a unilateral incentive to erect barriers to trade. Robert Torrens argued for reciprocity in trade liberalization based on the potentially adverse effects of a unilateral dismantling of England's trade barriers. Endorsing Torrens's claims, John Stuart Mill demonstrated that by levying an import tariff, a country could improve its "terms-of-trade" - that is, it could increase the price of its exports relative to its price of imports - and thereby enhance its share of the gains from trade. ${ }^{20,21}$ Charles Bickerdike (1906) formalized Mill's

${ }_{20}$ Mill recognized that the benefits from unilateral protectionism implied a need for international cooperation, writing that "it is evidently the common interest of all nations that each of them should abstain from every measure by which the aggregate wealth of the commercial world would be diminished, although of this smaller sum total it might thereby be enabled to attract itself a larger share."

21 The terms of trade thus measures the amount of imports that can be obtained for a unit of exports. In a two-good model, where a country imports one product and exports another, the terms of trade is simply the relative price of these two products. But with more goods, it is necessary to relate an index for import prices to an index for export prices. 
argument and developed a diagrammatic analysis to illustrate the determinants of the size of the welfare-maximizing trade tax.
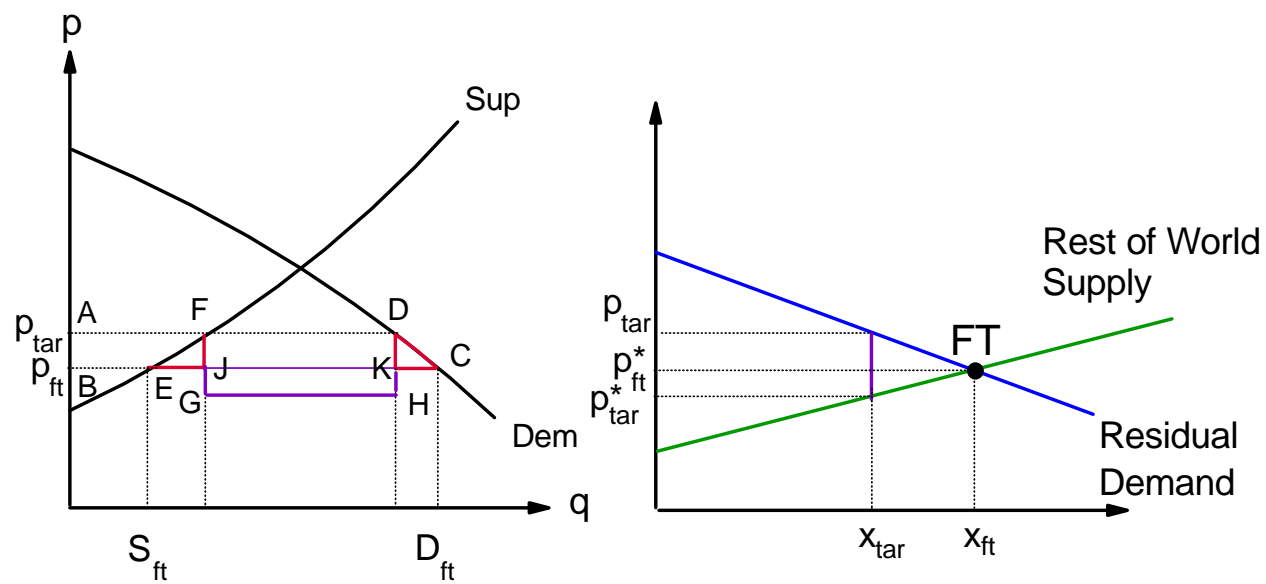

Figure 4: The Market for a Traded Product

The potential for national gains from unilateral protection are readily seen in a familiar supply-and-demand analysis of perfectly competitive markets. In Figure 4, the left-hand panel depicts a country's demand for an importable good and its supply of a competing good, each drawn as a function of the domestic price. The horizontal difference between demand and supply at any price measures the demand for imports; when derived as the difference between domestic demand and supply, as is done here, it is also sometimes denoted the "residual demand." It is depicted on the right-hand panel, along with the rest of the world's residual supply of exports (i.e., the world's total supply less the sum of the internal demands). The intersection of import demand and export supply at point $F T$ in the right-hand panel reveals the volume of trade, $x_{f t}^{*}$, and the terms of trade, $p_{f t}^{*}$ when the home country practices free trade. On the left-hand panel, $D_{f t}$ and $S_{f t}$ represent the corresponding free-trade levels of domestic demand and supply.

Now suppose that the government of the importing country implements a small tariff at ad valorem rate $t$. This policy drives a wedge between the price received by foreign suppliers and the price paid by domestic consumers. Domestic producers are able to sell at the higher domestic price, because their output is not subject to the tax. With the tariff in place, import demand still must balance the export supply, but the quantities demanded and supplied must reflect the prices faced by the agents in each country. In the 
right-hand panel, we show the volume of trade that balances demand and supply when the domestic price $p_{\text {tar }}$ exceeds the foreign price $p_{t a r}^{*}$ by the percentage $t$.

Notice that the importing country pays less to its trade partner for its imports with the tariff in place; that is, $p_{\text {tar }}^{*}$ is less than $p_{f t}^{*}$. This is the terms-of-trade improvement first identified by Torrens and Mill. The tariff discourages consumption in the importing country, while the associated protection of domestic producers encourages their production. For both reasons, the demand for imports shrinks. With less demand in the world market, the world price falls.

Returning to the left-hand panel, we can gauge the implications of the tariff for aggregate welfare in the importing country. The tariff has three effects on welfare. First, consumers lose from the rise in the domestic price from $p_{f t}^{*}$ to $p_{t a r}$. The loss comprises the increased amount they pay for the goods they continue to consume at the higher price and the loss of surplus that results from their contracting consumption. Since the demand curve reveals consumers' "willingness-to-pay," the total loss to consumers is the area represented by $A B C D$ in the figure. Second, producers benefit from the protection. They gain from receiving more for the output that they originally produced and also from the expansion in production. The supply curve reveals the (marginal) cost of the resources that go into production, so $A B E F$ represents the increase in profits. Finally, the government captures revenue from the tariff. The revenue is the equal to the volume of imports, FD, times the gap between internal and foreign prices, $p_{t a r}-p_{\text {tar }}^{*}$. In the figure, the tariff revenue is represented by FGHD. The government can use this revenue for instance to provide public goods valued by their constituents, to make payments to them, or to reduce their taxes. The government revenue can in turn be decomposed into two parts, reflecting the distribution of the burden of the tariff between domestic consumers and foreign producers: (i) the area FDKJ represents tariff revenue that is effectively collected from domestic consumers, who are paying a higher price on the units that they continue to purchase after the tariff is imposed; and (ii) the area JKHG corresponds to the reduction in foreign firms' profits stemming from the tariff-induced fall in the price these firms receive on the units they continue to sell with the tariff in place.

Neglecting the distributional implications for the time being, the net welfare effect for the importing country is the sum of the effects on consumers, producers, and the government. In the figure, this net gain is represented by the difference between the area of the rectangle JKHG and the area of the two triangles, EFJ and DKC. The former is a terms-of-trade gain for the importing country - the volume of imports with the tariff in place times the amount by which the tariff causes the world price to fall. The latter is the "deadweight-loss" - the inefficiency caused by reducing consumption below the point where the willingness to pay equals the opportunity cost in terms of the payment to 
foreigners and by increasing production beyond the point where the marginal cost of the resources used by the domestic industry equals the opportunity cost of importing the goods from the foreign industry. The area of the triangles is small when the tariff rate is small, because a small tariff generates only a modest loss of efficiency. When the tariff rate is small, the sum of these areas cannot be as large as the area of the rectangle, so a small tariff always generates a net welfare gain for the importing country. The traditional "optimum tariff" is the tariff level that balances the marginal gain from improving the terms of trade with the marginal loss from exacerbating the deadweight loss. Or, put differently, it is the tariff level at which the marginal reduction of consumer welfare is just balanced by the marginal increase in the surplus for import-competing industry and in tariff revenue. ${ }^{22}$

Note that the unilateral incentive that an importing country has to impose a tariff does not hinge on the partner country pursuing any particular policy. National incomemaximizing governments will perceive a benefit for restrictive policies no matter whether they expect the markets of their trade partners to be open or closed.

\subsection{The Basic National Market Power Model}

We have thus far considered the situation from the point of view of the importing country. We now ask, what is the impact of the tariff on a country's trade partner, and on global efficiency? As we just saw, for the importing country, there are two sources of deadweight loss: one stems from over production and the other from under consumption. But there is an offsetting gain, which is the portion of the tariff revenue that comes from the lowering of the international price of the imported product, or equivalently, the terms-of-trade gain on those units that continue to be traded after the imposition of the tariff. For the "Foreign" exporting country there are two types of costs. First, there is the reduction in the price of those units that continue to be traded after the imposition of the tariff. This loss is, of course, the mirror image of the importing country's gain, so in the calculus of global efficiency, the two effects cancel. The other cost borne by Foreign occurs

22 The benefits that a country derives from unilaterally restricting its imports or exports are analogous to those that a firm with market power derives from restricting its supply or demand. A large firm can significantly affect the price at which it sells its output and buys its inputs. It maximizes profits by selling less than the competitive supply, or if being a larger buyer, by buying less than the competitive demand. Similarly, a large country can improve its terms of trade by selling less than the free-trade supply of its exports and buying less than the free-trade demand for imports. This could, in principle, be achieved if the many domestic buyers of the imported product were to hold back their purchases, and if the many small domestic exporters were to hold back their sales. However, they are typically not able to coordinate on such arrangements. Instead, the government effectively helps them achieve the same outcome, when it imposes a tariff. 
because some units are not exported after the tariff is introduced, and the difference between the price at which they were traded under free trade and the (marginal) production costs reflects a deadweight loss imposed on the exporting country. The net effect of the tariff on global income comprises the three sources of deadweight losses. Put differently, while benefiting the importing country, the tariff necessarily is globally inefficient. Provided the exporting country could share the gains with the importing country, both governments could gain from a removal of the tariff. In the national market power approach, the basic rationale for a trade agreement is to enable such gains to be realized.

We have so far considered the effects of the unilateral imposition of a tariff by Home, while assuming that Foreign does not pursue any interventionist trade policy of its own. But suppose that there is another sector where the roles of the two countries are reversed, so that Home exports a product to Foreign, with Foreign possibly imposing a tariff $t^{*}$. The roles of the two countries depicted in Figure 4 would then be reversed in this other market.

Due to the assumed structure of the economy and government objectives, any positive tariff would reduce global national income. Each country imposes on the other a negative externality when it unilaterally introduces a tariff, since the increase in national income for the importing country government necessarily falls short of the reduction in income for the exporting country government. This model provides an example of a setting that fulfills the assumptions made in Section 3 concerning government objective functions $G\left(t, t^{*}\right)$ and $G^{*}\left(t, t^{*}\right)$, as was illustrated in Figure 2 . The difference between the two analyses is that the special model described here stipulates more precisely the supply and demand conditions, and government objectives, that give rise to a situation with international policy externalities.

The simple game-theoretic analysis that we developed in Section 3 can now be adapted to our special case. The outcome of such a policy game was first analyzed by Johnson (19531954). He presented a diagrammatic analysis similar to our depiction of a Nash equilibrium in Figure 2 above. ${ }^{23}$ In the equilibrium he considered, each government imposes a tariff in order to exploit its national market power. The resulting Nash equilibrium is globally inefficient, because each government disregards the distortionary effect of its tariff. This leaves room for a trade agreement to raise aggregate welfare for both governments by increasing trade.

${ }^{23}$ The analysis was subsequently developed by Mayer (1981), who gave it a more rigorous gametheoretic setting. 
Although we have illustrated the argument with reference to a policy that restricts imports, a similar argument applies also to export restrictions. By taxing exports, a country reduces the supply of those goods to the world market, thereby driving up the world price and generating a terms-of-trade improvement on the export side. For a small tax, the revenue generated by the government plus the gain to local consumers from the induced fall in the domestic price must exceed the profit loss that domestic producers will suffer as a consequence. In fact, economists usually explain the terms-of-trade argument for trade policy in terms of a general equilibrium in which resources flow between and among export sectors and import-competing sectors and households allocate their budgets among exportable and import goods. In this setting, what matters for welfare is the relative price of exports in terms of imports, which is what economists mean by the terms of trade. Either a restriction on imports or a restriction on exports can be used to improve a country's terms of trade.

\subsection{Discussion}

Section 3 showed how international externalities from unilateral policy setting provide a rationale for the formation of trade agreements, relying on a few plausible general assumptions about the properties of government objective functions. But because of the lack of detail with regard to government preferences and the economy in which governments interact, the model did not shed light on the nature of these international externalities. In Sections 4.1 and 4.2, we went to the opposite extreme and presented a stylized special case of the international externalities model, which depicts national income (or social welfare) maximizing governments that interact in a two-good, perfectly competitive economy. The attraction of this model is that it illustrates, in an analytically simple way, what most economists see as the core inefficiency that trade agreements are intended to address, namely the reduction in trade that results from unilateral tariff setting. But the model obviously relies on some very special assumptions. In what follows, we will discuss several aspects of the model, including how it can be generalized. We will mostly focus on the assumed government behavior, but we begin with a brief discussion of the assumed structure of the economy.

\subsubsection{The Structure of the Economy}

With regard to the assumed structure of the economy, the simple model makes a number of strong assumptions, such as there being only two countries and two goods, all markets being perfectly competitive, etc. But the economic environment in the model can readily be generalized in various ways without changing the basic conclusion that noncooperative policy setting generates tariffs that are too high relative to what is 
required for global efficiency. For instance, the model can easily be expanded to include many countries and any number of goods. Also, as shown by Bagwell and Staiger $(2009 a, b)$, and as argued in the companion study Principles of World Trade Law: Border Instruments, similar conclusions may be drawn in settings with imperfect competition and with firm-level economies of scale. Consequently, the simplicity of the model with regard to the structure of the economy should be seen as a strength rather than a source of concern.

\subsubsection{Do Countries Have Sufficient Market Power?}

It is hardly controversial to claim that some large countries, like the United States or China are sufficiently important buyers of many of the products they import so that their purchase decisions affect world prices. For these countries, the assumption of national market power seems highly appropriate, although there is still a question of whether their market power is sufficiently great to explain the levels of protection that would prevail absent the GATT/WTO. ${ }^{24}$ The more difficult issue is how to view the market power of smaller members of the WTO. Is it reasonable to assume that these countries have some impact on prices in world markets and that this motivates their inclusion in the trade agreement?

First note that even small countries may be important players in the markets for certain goods and may have significant market power in these markets. Transport costs may limit the geographic extent of the market for some goods, rendering the relevant market as a regional one in which relatively small countries are nonetheless big players. Many natural resources are found mainly in a small number of countries, so that the producers of these resources enjoy market power. Also, goods from different origins often are imperfect substitutes in the eyes of consumers, so that the producers of the differentiated goods can affect prices in a market niche. Moreover, most countries tend to export relatively few products compared to how many they import, and this specialization in production tends to create national (and/or firm-level) market power. For all of these reasons, even seemingly small countries may have an influence on world prices.

Be that as it may, the WTO includes as members many very small countries along with many more that are small with respect to most world markets. What incentives do such

${ }^{24}$ We refrain from discussing a recent empirical literature that seeks to shed light on the extent to which tariffs can be explained by national market power, as exemplified by Broda, Limao, and Weinstein (2008), Bagwell and Stagier (2011), and Ossa (2011). This literature is highly relevant to the issue at stake here, but the literature is still in its infancy, and it would take our discussion into conceptually too difficult issues. 
countries have to join the trade agreement, and what incentives do the large countries have to include them? One answer is that the reason for their joining and the reason for including them need be no different than for larger countries: by including a small country in the agreement, the larger trade partners can avoid a small negative spillover at a still smaller cost to themselves. By including many such countries in the agreement, the potential gains for the governments of the large countries could be substantially greater. There can thus be scope for an agreement that includes many small countries, even if the trade restrictions that these countries would apply if they were not members would be rather low.

Even if the small countries in the world trading system would not form an agreement among themselves if such an agreement did not already exist, these countries might well choose to become members of a trade agreement concluded among the larger countries in order to benefit from Most-Favored Nation treatment and to avoid facing the higher trade barriers imposed on nonmembers. Of course, an agreement designed by the larger countries need not be ideal from the perspective of small-country governments, since with few valuable concessions to offer, the small countries might have little influence over the terms of a multilateral agreement. ${ }^{25}$ The specific reductions in trade barriers agreed by the larger countries need not benefit the smaller trade countries compared to the barriers that would obtain in the absence of any multilateral agreement. But the fact that the government of a small country might prefer a world trading system without cooperation to one in which the large countries choose the terms does not imply that the small countries would prefer to stay out of any agreement that is reached; the small countries face a choice of joining or not, but do not have the means to enforce the benchmark outcome without any cooperation.

As we have seen, there are several reasons to believe that the national market power may be a driving force behind the membership both of larger and of smaller countries in trade agreements. But it does appear that many small countries erect trade barriers that are much higher than what can be explained by the potential exploitation of their world market power. This may primarily be explained by the influence of special interests in these countries, as we have noted above. But the high tariffs imposed by many small countries may be explained by several additional factors. For instance, these countries may lack capability to enact and enforce taxes on sales or income, leaving trade taxes as the administratively simplest way to government revenue. Alternatively, some countries may have a cultural reluctance to integrate into the world economy. Or, the consumer

25 This statement assumes that the small countries cannot band together to form a coalition. If they can do so, they can act collectively like a large country. 
interest may be particularly weak and politically underrepresented in some small developing countries.

\subsubsection{Richer Descriptions of the Politics of Trade-Policy Formation}

Let us next turn to the assumptions concerning government objectives. The basic model seemingly provides an unrealistic depiction of the domestic politics of trade-policy choices. It is tempting to believe that governments rarely seek to maximize national income as their sole objective (although strictly speaking, such a claim should be verified empirically, and not simply be postulated). It therefore seems important to incorporate, into the modeling of trade agreements, a more realistic description of the political process, both as regards the incentives that governments perceive in making their policy choices absent any agreements and the incentives they have to form an agreement. Fortunately, the economics literature on trade policy has made great progress in generalizing the basic model to include richer descriptions of domestic politics.

As far back as the 1970s and even earlier, economists and political scientists have been studying how trade policies are formed via the interaction of the government, voters, and the private sector. The earlier attempts offered some interesting insights and hypotheses, but they were often based on models and approaches that lacked the analytical rigor demanded in other areas of economics. But, in the last couple of decades, the research on the political economy of trade policy has made great progress, and the models of the political process that have been developed are every bit as sophisticated as those long used to model the economy. For example, Dixit and Londregan (1996) analyze policy formation in a polity in which two parties compete for votes in many electoral districts. They find that redistributive policies favor districts with relatively many "swing voters"; i.e., voters who find the ideological positions of the parties to be similarly appealing or unappealing. In the context of trade policy, their finding predicts protection for industries that are geographically concentrated in districts (or states) with many centrist voters. Grossman and Helpman (1994, 1995a, 1995b) examine trade policy formation in an environment in which politicians covet campaign contributions. When special interests offer contributions in exchange for implicit promises of policy favors, the resulting trade policy caters to the concerns of organized interests. The trade policies that emerge from the political contest are those that maximize a weighted average of aggregate welfare and the welfare of special interests in politically organized industries. Several other politicaleconomy models of trade-policy formation have a similar feature.

Despite the wide variety of political interactions that are highlighted in these more sophisticated analyses, the models share certain features with the simple national market 
power model laid out in the previous section. In particular, the models with more realistic depictions of politics still predict that unilaterally-chosen trade policies will be excessively restrictive compared to what would generate global efficiency, due to the continued presence in these models of a temptation for governments to exercise their national market power. As argued by Bagwell and Staiger $(1999,2002)$, the models with richer depictions of the political process offer fundamentally the same explanation for the existence of trade agreements as does the more basic model described in Section 4.2. Governments may set positive tariffs to cater to particular constituents, but the resulting tariffs will be even greater than what would result from constituent pressures due to the temptation they have to exploit national market power. The models with domestic politics may provide more realistic predictions about the level of protection absent an agreement, but they provide a similar explanation as models of national-income maximizing governments as concerns the incentives for international cooperation.

\subsubsection{The Role of Tariff Revenue}

The national market power model has been questioned by some on the grounds that it relies too heavily on the collection of tariff revenue as an incentive for governments to impose tariffs. Some observers have gone as far as to argue that tariff revenue is completely irrelevant to developed country governments when they set trade policies. ${ }^{26}$ If one were to assume, contrary to the standard model, that the government's objective function puts no weight on tariff revenue whatsoever, then a national-incomemaximizing government would have no reason to invoke positive tariffs and therefore no reason to enter into a trade agreement with other governments that behaved similarly. This can be seen from Figure 4, where the national benefit of the tariff is represented by the rectangle $J K H G$, a portion of the country's tariff revenue.

It is true that tariff revenue does not figure in the policy debates of most countries as a motive for trade restrictions, and it is rare to hear governments of developed countries refer to tariff revenue as a rationale for their tariffs. Still, we do not find the criticism to be entirely compelling.

First, as a matter of theory, while tariff revenue plays a central role in the work-horse model of trade agreements that assumes national-income-maximizing governments, it is less central in other models building on national market power. To illustrate, consider the Grossman and Helpman (1995a) model of political influence and suppose that the government puts a zero weight on social welfare and cares only about its campaign contributions. Then the tariff revenue would not directly affect the government's

${ }^{26}$ See, for example, Ethier (2006) and Regan (2006). 
decisions about tariffs. Assume further that the special interests are concentrated in a very small fraction of the population, so that the members of the interests groups obtain only a negligible fraction of the redistributed tariff revenue. The special interests will then neglect tariff revenue when deciding about their campaign contributions. In this case, governments will choose their tariffs solely in view of the campaign contributions they are offered, which will in turn be based on the protection that special interests gain from tariffs and not on the revenues that are generated. Nonetheless, the tariffs that the governments will set will be inefficiently large when viewed from the perspective of the politically-influential interest groups in all countries taken together, and there will be scope for the governments to negotiate a trade agreement.

Second, governments do generally behave as if tax revenues matter to voters and constituents. Politicians need revenues to finance government spending on projects that are valuable to voters and for transfer programs that gain them political support. They are reluctant to raise income taxes and pay a political cost when they do so. On the margin, tariff revenues allow the government to spend more than it otherwise could or to maintain lower income and other tax rates than otherwise. If governments care about their finances, as surely must be the case, then they should also care about tariff revenue. It is not essential that voters and constituents recognize the link between tariffs and public spending, or between tariffs and other tax rates, for the government to behave as if the tariff revenues are valuable. Rather, it is enough that voters see benefits from public goods and that they dislike other forms of taxes. Then, a government that recognizes a (long-run) budget constraint should be expected to place a positive weight on tariff revenues as a means to provide voters and constituents with valued goods and services.

\subsubsection{Labeling the Government Behavior That Trade Agreements Address}

At a general level, the role of a trade agreement can be described as helping countries to prevent international externalities from unilateral tariff setting. But more descriptive labels are often used to describe the problem that trade agreements are intended to solve. The designation of a very precise role for a trade agreement is a somewhat elusive task, however.

It is common in the literature to link the role of trade agreements to the unilateral incentives facing governments. For instance, Bagwell and Staiger (1999) focus on the incentives of governments to improve the terms of trade: ". . trade agreements are appealing to governments solely as a means to remedy the inefficient terms-of-tradedriven restrictions in trade that arise when trade policies are set unilaterally. . .." This 
notion is often criticized, however. Critics assert that the notion of terms of trade hardly ever figures in the policy debate, and that governments rarely deliberately seek to depress prices of imports, or increase the world prices of exports. Partly in response to this objection, Hillman and Moser (1996) describe the problem that trade agreements address as stemming from governments' unilateral incentives to restrict market access due to the perceived benefit from preserving sales in their home market for local firms. This terminology is, of course, much more in tune with what policy makers seem to care about than the notion that governments impose import restrictions in order to improve the terms of trade.

But Bagwell and Staiger (2002, p. 30) argue that there is no real distinction between the two views on the unilateral incentives for governments: because of the intrinsic interrelationship (or duality) between prices and quantities, one might equally well assume that governments worry about the terms of trade or about market access. To see how, think of the standard downward sloping schedule that relates the quantity demanded to price. We can either view the graph as illustrating the quantity that will be purchased at each price, or as illustrating the price that consumers are willing to pay for each quantity - the two formulations reveal exactly the same information. Similarly, Bagwell and Staiger would argue, it is immaterial whether we assume that governments are concerned with the price of their imports for any imported quantity-the terms of trade-or about the quantities being traded at a given price-the market access. The alternative terms just reflect two sides of the same coin: an improvement in the terms of trade goes hand in hand with an improvement in market access; when governments request better access for their firms to foreign markets, they are also requesting higher export prices for the initial volume of exports, or equivalently, better terms of trade. Negotiations about market access can thus be regarded as negotiations about the terms of trade, even if the governments are unaware of this equivalence. ${ }^{27}$

Regardless of how we view government motives, it is not the change in terms of trade as such that is the problem with unilateral tariff setting: when both countries impose tariffs, the effects on the terms of trade will tend to counteract one another. It is even possible that the two, offsetting tariffs will leave the terms of trade approximately where they would have been under free trade. But the tariff-ridden equilibrium will still yield less welfare for the parties compared to what could be achieved with free trade, or with an efficient trade agreement, because the lesser volume of trade means fewer gains from

27 This argument might not adequately reflect protectionist motives for being concerned about market access. For instance, Regan (2006) argues that for a protectionist government, the increase in domestic production is the desirable consequence of the imposition of a tariff. But for a government that seeks to improve the terms of trade, the reduction of the imported volume is undesirable as such, but is the means through which the improvement in terms of trade is achieved. Accordingly, the two views do not seem to simply reflect two sides of the same coin. 
trade. The more fundamental problem caused by unilateral tariff setting is that governments reduce trade volumes in order achieve their objectives, whatever they may be. Consequently, it seems appropriate to identify the fundamental rationale for trade agreements as to induce governments to internalize the externalities that result from their unilateral reductions of import demand and export supply.

\subsection{Are Predictions from the National Market Power Model Compatible with the Design of the GATT?}

A minimal requirement for our theory of trade agreements is that it should identify a plausible rationale for the existence of the GATT (or WTO). But it is also highly desirable that the theory should be compatible with the salient features of the GATT, and in particular that the theory should explain how some of these features contribute to solving the problem that the theory identifies as the rationale for the agreement. This is desirable for at least two related reasons. First, the extent to which the model seems to explain core features serves as a "reality check," in the sense that if most core features of the GATT seemed incompatible with model's predictions, it would be difficult to argue that it captures the essential rationale for the existence of the GATT. Second, the purpose of this project is not to explain the existence of the GATT - although this would be a worthy task on its own-but to contribute to improving the interpretation of the text. We would be much abetted in this task if theory could help us to explain the broad purposes of the provisions to be analyzed.

In this section, we will point to a number of features of the GATT that are notable when the agreement is viewed from an economic perspective and we will very briefly discuss the extent to which a national market power approach can shed light on these features. By necessity, the analysis will have to be superficial; however, most of the features mentioned here are discussed more fully in the accompanying study Legal and Economic Principles of World Trade Law: Border Instruments. Whether a feature is deemed "notable" is of course highly subjective, and other observers might point to different features than those mentioned here. Moreover, the national market power approach encompasses a large number of different contributions, and it is not possible to evaluate the contributions of each separate model. Instead, we will discuss in broader terms whether national market power seems to be an important part of the rationale for a variety of observed features. Our general conclusion is that the national market power model does provide plausible explanations for a number of core features of the GATT, or is at least broadly compatible with these features. But we will also point to some aspects of the GATT that are harder to fit into the model. 


\subsubsection{Border Instruments Are Regulated, But Alternative Policies Are Treated Differently}

The basic restrictions imposed by the GATT are ceilings on permissible levels of border instruments. Such ceilings make eminent sense from the perspective of the national market power model, since a basic proposition from the model is that governments will impose trade measures that are too restrictive if they are chosen unilaterally. But not all border measures are treated similarly by the GATT/WTO. Quantitative trade restrictions are illegal by virtue of GATT Article XI both on the import and the export side, while fiscal measures are treated much less categorically. Meanwhile, export subsidies were treated rather permissively in the early GATT years (under GATT Articles XVI and VI), but are now illegal by virtue of the WTO Agreement on Subsidies and Countervailing Measures (SCM). In contrast, export taxes are treated symmetrically with import tariffs under GATT Articles II and XXVIII bis, and therefore are legal. In principle, export taxes could be bound just like tariffs (although Art. II GATT only refers to importation), but in practice they are not; we return to export taxes and subsidies below. Somewhere in between these extremes are tariffs, which are legal, but the maximum height of the taxes are bound through negotiation.

The GATT's hostile attitude toward quantitative trade restrictions is superficially compatible with the general theoretical proposition that quantitative trade restrictions are more distortionary than fiscal measures when employed to achieve the same objective. ${ }^{28}$ But in order to explain why the GATT prohibits such measures, we need to explain why they are used at all, since if they are not used, there is little reason to prohibit them. We also need to explain why the externalities from quantitative import restrictions are likely to be worse than those from tariffs - if they are not, we have no explanation for why the parties would steer permissible protection over to tariffs. It is far from obvious how to explain either of these features, however. The extra distortionary costs from quantitative measures that theory identifies are typically borne by the country imposing them. This suggests that countries should prefer to employ tariffs rather than quotas. It also suggests that countries might impose less protection in case they have to rely on quotas, these being more costly to the importing country than tariffs. If so, it would seem appropriate that the agreement bans tariffs rather than quotas, in order to reduce international externalities..$^{29}$ We are led to conclude that the national market power approach does not

${ }_{28}$ Although an import quota and an import tariff can be made equivalent in all respects under very special circumstances-essentially those that are assumed in the basic national market power model, but with only one country being policy active-in many situations it will be less costly in terms of distortions to employ tariffs rather than import quotas to achieve a given level of imports.

${ }_{29}$ An additional layer of complexity appears when we take into consideration the self-enforcement constraints. As discussed above, the degree of liberalization that can be achieved through a self-enforcing 
provide a simple explanation for one of the more fundamental aspects of the GATT, namely its preference for fiscal measures over direct regulation of trade volumes.

\subsubsection{The Emphasis on Reciprocity}

Reciprocity arises in two forms in the GATT/WTO, referring as it does to a balance of concessions between parties. First, it appears in the rules concerning renegotiations of tariff bindings: Art. XXVIII.2 GATT stipulates that such renegotiation must maintain the reciprocal balance of concessions that had been agreed previously. Second, reciprocity is frequently mentioned in more general statements concerning tariff negotiations. For instance, after listing a number of objectives that the GATT is to achieve, the Preamble of the GATT states the following:

Being desirous of contributing to these objectives by entering into reciprocal and mutually advantageous arrangements directed to the substantial reduction of tariffs and other barriers to trade and to the elimination of discriminatory treatment in international commerce....

Here, reciprocity has been interpreted more as a norm than as a legal requirement. The more precise meaning of this norm has not been well developed in the GATT/WTO, however.

Reciprocity in the second sense could be given a rather strict interpretation. Such a stance is illustrated by the following passage from the final report by the USTR on the Kennedy Round of GATT negotiations, which explains the various criteria used by the USTR in measuring reciprocity:

In order to simplify the presentation, the results of U.S. participation in the Kennedy Round tariff negotiations are presented in this report solely in terms of the value of trade covered by the concessions and the depth of the tariff reductions. However, in the course of the negotiations, numerous other factors were considered in evaluating the balance of concessions-the height of duties, the characteristics of individual products, demand and supply elasticities, and the size and nature of markets, including the reduction in the disadvantage to U.S. exports achieved through reductions in the tariffs applied to the exports of the United States and other non-member countries by the European Economic Community (EEC), the European Free-trade Area (EFTA) and those countries in

agreement depends on the extent to which the parties have incentives to punish deviations from the agreement, and the effectiveness of these punishments. It seems to be an open question whether quantitative restrictions perform better in this regard. 
the British Commonwealth preferential system. (U.S. Office of Special Representative for Trade Negotiations, Report on United States Negotiations, 1967, Vol. I, p. iii.).

Alternatively, "reciprocity" could be seen more as a bargaining norm, and this is the path that the bureaucrats have followed in later work. For instance, a GATT Working Party responded to a proposal by Brazil to adopt a definition of reciprocity as follows:

... the Working Party noted that there was nothing in the Agreement, or in the rules for tariff negotiations which has been used in the past, to prevent governments from adopting any formula they might choose, and therefore considered that there was no need for the CONTRACTING PARTIES to make any recommendation in this matter. (GATT, BISD, Third Supplement, p. 22)..$^{30}$

Evidently, the emphasis on reciprocity extends as a negotiating norm to general GATT/WTO tariff negotiations, and seems to reflect the balance between the trade effects of concessions offered and received.

Both notions of reciprocity can be explained within a national market power model. ${ }^{31}$ It is an intrinsic nature of any negotiated settlement in a situation where parties expose each other to externalities, that the parties exchange concessions. It may appear as a rather selfevident feature to demand of any model of the formation of trade agreements that it should feature this form of reciprocity. But, as discussed in Section 5, not all models purporting to explain the existence of trade agreements share this feature.

\subsubsection{Border Instruments Are Regulated, But Domestic Instruments Are Not}

Section 3.4.3 points to a fundamental difference in how GATT treats internal domestic policies and border instruments. The use of policies that apply to goods as they cross international borders typically is regulated by the trade agreement. But the GATT leaves governments with broad discretion to set their own internal policies, only imposing general constraints on how this discretion can be exercised. It is clearly desirable that a

\footnotetext{
30 This and the previous quote are from Hoda (2001).

31 For instance, Bagwell and Staiger (1999) argue that reciprocal tariff reductions in the GATT context can be understood as reductions that maintain the terms of trade. This interpretation sheds light on both Art. XXVIII GATT renegotiations, and general tariff negotiations.
} 
theory to be used to interpret the GATT contributes to explaining this characteristic of the agreement.

There is a fairly large body of literature that studies various aspects of the incompleteness of trade agreements. This literature assumes almost exclusively that the basic role of trade agreements is to prevent governments from seeking to exploit national market power, and it focuses on the extent to which the agreements prevent governments from using domestic instruments for such purposes. National market power does not as such explain the incompleteness of trade agreements-most of the literature studies the impact of exogenously imposed restrictions on what governments can regulate in an agreement, although there are recent attempts to explain the structure of trade agreements from a

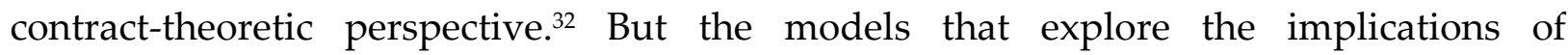
contractual completeness do make use of the national market power approach as their explanation for the existence of a trade agreement in the first place.

\subsubsection{The Most-Favored Nation Principle}

While the GATT/WTO prohibits the use of certain border measures, it leaves significant room for the member governments to either negotiate bindings on other policies - as in the case of tariffs-or to set the levels of policies unilaterally. The parties are not completely unconstrained in this regard, however. Two nondiscrimination clauses constitute basic restrictions on permissible policies. These are the Most-Favored Nation (MFN) clause in Art. I GATT and the National Treatment (NT) clause in Art. III. The MFN clause applies to any type of border measure, and (by virtue of the reference to Art. III GATT, which we discuss below) also to any type of domestic measure. It stipulates that an imported product originating from one member country must be treated no less favorably than a like imported product from any other country with regard to virtually any government policy. The provision is widely viewed as one of the cornerstones of the GATT/WTO.

There is a fairly large literature on MFN. Most studies build on the national market power model, and analyze its consequences for trade, and for tariff liberalization. Some contributions to this literature also suggest reasons for the inclusion of this provision in trade agreements. From the point of view of the national market power approach, this is

32 Early papers in this literature include Copeland (1990) and Hungerford (1991), which highlight consequences of exogenously imposed contractual incompleteness. Horn, Maggi, and Staiger (2010) show how contracting costs may explain why border instruments are bound but not domestic instruments. 
of course reassuring. But interesting insights into the rationale of MFN are also provided by studies using alternative approaches..$^{33}$

\subsubsection{The National Treatment Principle}

Although the NT clause shares certain general features with MFN, its ambit is different. Whereas the MFN clause applies to all policies, whether pursued at the border or domestically, NT only applies to domestic policies. Moreover, whereas the MFN clause applies to a comparison of similar products from different sources of imports, NT restricts the relative policy treatment of imported versus domestically-produced products.

There is a small economics literature on NT. As in the case of MFN, most of this literature is compatible with, and builds on, the national market power approach. ${ }^{34}$ This literature is described in more detail in the accompanying study Legal and Economic Principles of World Trade Law: National Treatment.

\subsubsection{Rules Concerning Preferential Trading Agreements}

While the MFN provision is seen as a cornerstone of the GATT/WTO, it is singled out almost as often for its exceptions as its rule. The main exception can be found in Art. XXIV GATT, which allows for the formation of preferential trading arrangements (PTAs). These arrangements are by their very nature discriminatory, as is acknowledged through the term "preferential." They allow subsets of GATT/WTO member countries to eliminate tariffs on one another's trade while maintaining positive (but common) tariffs against other GATT/WTO member countries who are not part of the arrangement. The apparent contradiction between the MFN principle and Art. XXIV GATT raises fundamental questions about the purposes of the various provisions, and also about the precise way in which the rules governing the formation of PTAs have been formulated.

A large economic literature-too vast to cite here-studies various aspects of PTA formation, in a large variety of different economic settings. This literature often employs models with similar mechanisms as in the national market power model. It thus seems fair to say that the mechanisms that are captured in the national market power model help to explain the incentives that countries have to form PTAs, and to some extent also the GATT rules that regulate their terms (such as the requirement that tariffs against non-

${ }^{33}$ For a discussion of the literature, and for references, see Horn and Mavroidis (2001), and Schwartz and Sykes (2002).

34 Horn (2006), and Saggi and Sara (2008), analyze implications of exogenously imposed NT-like provisions. Horn, Maggi, and Staiger (2010) show how contracting costs might explain the existence of such a provision. 
PTA countries must not increase as a result of the formation of the PTA). But we are not aware of any analyses of the rationale for Art. XXIV that point to national market power as the underlying force.

\subsubsection{Possibilities to Escape Bindings}

From the inception of the GATT it was anticipated that governments might need to escape from negotiated tariff commitments. Flexibility is provided by Art. XIX GATT for temporary escape and in Art. XXVIII GATT for permanent escape. The WTO Agreement contains additional understandings and agreements related to each Article. Of particular significance is the accompanying Agreement on Safeguards, which represents an attempt to clarify and strengthen the mechanism for members to unilaterally withdraw concessions with regard to tariffs for a limited period of time.

The economic literature contains some analysis of safeguards and renegotiations in trade agreements. To the best of our knowledge, most of the literature develops frameworks that are based on the national market power model. In these models, governments have incentives to impose tariffs in order to exploit national market power, thus exposing trade partners to negative externalities, and the basic purpose of the agreement is to induce governments to internalize these effects. But the design of the optimal agreement is more complicated than usual, because it is assumed that random exogenous events can affect the efficient degree of trade liberalization. The literature considers various aspects of this contracting problem, such as for example the balance between the need to check members' unilateral incentives to pretend injury in order to exploit national market power and the desire to allow them to escape bindings in situations where this is efficient. ${ }^{35}$

The national market power model does not by itself explain the inclusion in the agreement of possibilities for temporary escape and for permanent renegotiations in the GATT. But the focus in this approach on international efficiency makes it a natural starting point to study such mechanisms.

35 For a recent extensive analysis and for references, see Bagwell and Staiger (2005), and Herzing (2005). A number of reports in the case-law part of this project discuss the role of safeguards in the WTO, See, e.g., Bagwell and Sykes (2004), Grossman and Mavroidis (2004a), Grossman and Sykes (2006), and Horn and Mavroidis (2004a). See also Regan (2006) for a critical discussion of the ability of the national market power model to capture salient features of WTO safeguards. 


\subsubsection{Gradual Trade Liberalization}

A direct application of any of the international externalities models discussed above would suggest that the founders of the GATT should have negotiated efficient tariffs once and for all. Instead, one of the distinguishing features of the GATT/WTO has been its very gradual process of tariff liberalization, agreed upon though a series of tariff negotiations since its inception. This gradualism does not apply only to the rate at which tariffs on individual goods have been lowered; it applies as well to a number of other dimensions of the GATT/WTO, including the gradual expansion of GATT/WTO coverage to additional product categories and issue areas and the gradual expansion of GATT/WTO membership. Clearly, the gradual nature of trade liberalization in the GATT/WTO represents an important feature of the multilateral agreement.

A fairly sizeable literature seeks to explain gradualism in trade negotiations. The gradualism might stem from various causes, but a common assumption is that certain factors of production, such as human capital, move sluggishly from one sector to another in response to changes in prices. As a result, it may be desirable to lower trade barriers slowly, to allow time for the factors to adjust. Several of these models assume that the purpose of a trade agreement is to internalize externalities from exploitation of national market power, although the gradualism in the model does not stem from this particular objective for an agreement. ${ }^{36}$

\subsubsection{Export Taxes Are Legal}

The national market power model is compatible with, or can even be used to plausibly explain, most of the core features of the GATT that we have pointed to above. We now come to a pair of characteristic features of the GATT/WTO that are much more difficult to reconcile with this approach. These problems go to the heart of the national market power model, since they directly concern government incentives and possibility to change the terms of trade in their favor.

Before pointing to the problem, let us briefly explain a feature of trade policies that is known as "Lerner symmetry." 37 It appears in general equilibrium analysis and takes its sharpest form in a standard two-good, two-country framework. The Lerner symmetry theorem states that, in such a setting, an export tax at some ad valorem rate has exactly the same effects on resource allocation and welfare as an import tariff at the same rate. To

\footnotetext{
36 See, e.g., Bagwell (2009), Chisik (2003), and Maggi and Rodríguez-Clare (2007), for analyses and further references to the literature.

37 See Lerner (1936).
} 
gain some intuition for this somewhat surprising symmetry property, note that the direct effect of an import tariff is to increase the domestic prices in the import-competing sector. This will have the general equilibrium ramification of attracting productive resources in the export sector to shift into the import-competing sector, while discouraging consumption of this good. The direct effect of an export tax rather is to reduce domestic prices in the export sector, which stimulates resources to move out of the export industry and encourages consumption of the export good. In short, the alternative measures have the same influence on the relative price, they encourage resources to move in the same direction, and they induce similar incentives for consumers to substitute in their purchases. The complete symmetry between an import tariff and an export tax breaks when there are more than two goods. ${ }^{38}$ But it will still be possible to use export taxes to stimulate production in import-competing industries.

With this background, let us now turn to the role of export taxes in the GATT. As noted above, governments' use of export taxes is hardly restricted by the GATT. It would be possible to negotiate bindings, just like those for tariffs, but this has not occurred to any significant degree. As noted by Ethier $(2004,2006)$, this feature of the GATT does not seem to fit very well with the national market power model. The model proposes that tariffs are bound in order to prevent governments from restricting imports that can be used to exploit national market power. But Members have the economic and legal possibility to use export taxes for a similar purpose. It might seem implausible in the light of the GATT's failure to regulate export taxes that the purpose of the agreement could be to prevent the exploitation of national market power.

In our view, the GATT's failure to regulate export taxes is not fully consistent with the national market power model. But there are several reasons why the critique is not as severe as is sometimes argued, and why the incentives to use export taxes may not be as strong as the argument above suggests.

First, the fact that GATT Members largely abstain from using export taxes even absent any legal restrictions can be explained within a national market power model, such as the one of Grossman and Helpman (1995a), if it is assumed that the weight on domestic interests relative to aggregate welfare in governments' objective functions is sufficiently high. The governments would then refrain from imposing export taxes, even if they were perceived as beneficial from an aggregate welfare point of view, due to the harm they do to special interests in export industries.

38 According to a weaker Lerner Symmetry theorem, applying to the case of more than two goods, a uniform import tariff at the same rate on all import goods is equivalent to a uniform export tax at that rate on all export goods. 
Second, export taxes might have politically unattractive features: the direct effect is to push resources in the export sectors into unemployment, and depress the rents to the specific factors in these sectors. Then as the rewards to these factors fall, they will gradually move to other sectors. This process is likely to take considerable time, and will be a hard sell from a political point of view for any government with a short time horizon. The process would be further delayed to the extent that there are nominal rigidities, in the form of inflexible prices and wages. It is thus doubtful whether there would be political gains to be had from taxing or other restrictions on exports. Indeed, as argued by Ethier (2004), the political process seems to disproportionately reward the direct effects of policy measures, and the direct effects of export taxes are likely to have adverse implications for the popularity of incumbent governments.

Third, it would require a very good understanding of the workings of the general equilibrium system in order to replace a system of tariffs by a corresponding system of export taxes, if the two systems are to have the same economic effects. Tariffs are bound in the WTO mostly at the six-digit Harmonized System level, with many countries binding thousands of tariff levels. It is simply not a practical possibility to compute a system of export taxes that would come anywhere near having the same effects. Of course, this argument presupposes that imposing import barriers is simpler. But intuitively, this seems to be the case, and in any event, this is the historical record with which countries become members of the GATT/WTO.

Fourth, even if governments rarely use export taxes, there are still instances when they do-the recent China-Raw Materials dispute is an example of this. But governments also sometimes use other forms of export restraints that generate terms-of-trade gains, just like export taxes would. For instance, some countries have more permissive approaches toward cartels in export industries than in other sectors. An export cartel can achieve similar allocational effects as would an export tax, the main difference being that the surplus of the measure shows up as increased profits for cartelized firms, rather than as tax revenue for the government. The US-Export Restraints dispute concerned yet another form of export restraint. ${ }^{39}$

Finally, the fact that there are hardly any bindings of export taxes in the GATT does not by itself imply that governments are free to use export taxes freely. If countries started using export taxes, they would likely be bound through negotiations just like tariffs. Hence, while the lack of export tax bindings may say something about the desire of

\footnotetext{
39 Janow and Staiger (2003a) provide an economic analysis of issues raised in this dispute.
} 
governments to impose such taxes, it does not say much about what would be the eventual treatment of such instruments if they were to be used more extensively.

\subsubsection{Subsidies Are Restricted}

The MFN and NT provisions place broad limitations on discrimination by WTO Members in their choices of both border and internal measures. But the existing trade agreements also place specific limits on the use of domestic and export subsidies. We have already mentioned the prohibition on the use of export subsidies in the GATT/WTO, observing that this treatment evolved from one of relative permissiveness in the early GATT years to outright prohibition under the WTO SCM Agreement. The SCM Agreement prohibits also a second type of subsidy, one that is conditioned on the use of a domestically produced import. The SCM Agreement does not make domestic (production or factor-use) subsidies illegal per se, but it does designate some such subsidies as "actionable" based on the external harm they induce. This harm can arise both when an importing country displaces imports by subsidizing a domestic industry producing a like product, and when the subsidy adversely affects an exporter of a like product in a third market. Again the treatment of these domestic subsidies has evolved over the years: in the GATT years, the domestic subsidies of a member government could be challenged, but only if they upset the legitimate expectations of market access negotiated with another member government.

A fundamental aspect of export subsidies is that they worsen the terms of trade of the subsidizing country. As pointed out by, e.g., Ethier (2011), this does not square well with the notion that the purpose of the GATT is to steer countries away from seeking unilaterally to improve their terms of trade. But the prohibition of export subsidies can still be understood within an international externalities framework, such as the Grossman and Helpman (1995a) model: Suppose that each politically motivated government has strong preferences for its import competing interests, but also subsidizes exports, due to a strong weight on profits of export interests. These subsidies will then generate negative externalities, being set without consideration of the harm they do to foreign import competing interests, and there will consequently be scope for an agreement between the governments to internalize these externalities.

A prohibition of export subsidies can also partly be understood even for governments that maximize social welfare or national income, especially in markets that are imperfectly competitive. In such a setting, each government may face a unilateral incentive to subsidize exports in order to shift profits to its domestic producers. But the subsidies by each exporting government will worsen the terms of trade for other 
countries that export similar goods. It may be that all exporting countries lose as a result of their collective subsidies even though each alone has an incentive to do so. If so, the export subsidizing governments might prefer to prohibit subsidies. However, note that such a prohibition would adversely affect the interests of import-competing countries, and so a prohibition on subsidies might not be reached if all governments (and not just those of exporting countries) are parties to the international negotiation.

\subsubsection{Anti-dumping}

The most difficult feature of the GATT for the national market power model to explain are the agreement's rules concerning anti-dumping duties as embodied in Art. VI GATT and in the Agreement on the Implementation of Article VI of the General Agreement on Tariffs and Trade 1994. These complex rules can loosely be described as permitting importing countries to impose duties when foreign firms price discriminate by charging lower prices in their export markets than at home, or when these firms set export prices that are below some constructed measure of production costs. The problem that the national market power approach has in explaining these provisions is, of course, that importing countries should welcome low import prices. There would not be any deeper inconsistency between the treatment of dumping in the GATT/WTO and the national market power approach if the exporting firms did not change their pricing behavior in response to the threat of anti-dumping duties; with export prices constant, anti-dumping duties would serve to transfer revenues from the exporting firms to the importing government, which would represent an improvement in the terms of trade. However, anti-dumping duties are intended not to raise revenue, but to induce the foreign firms to increase their export prices, since these can avoid paying the duty by doing so. As formulated, the antidumping regime thereby generates a deterioration of the importing country's terms of trade. Accordingly, these provisions stand in sharp conflict with the logic of the national market power model.

\section{Trade Agreements as Government Commitment Devices Vis-à-Vis Constituent Interests}

In the discussion thus far, the overriding purpose of trade agreements has been to mediate the strategic interaction between governments. A smaller economic literature highlights what sometimes is presented as an alternative view of trade agreements, according to which the purpose of these agreements is to provide a mechanism for governments to commit to liberal trade policies, and thereby resist the pressures from their own domestic interests. This literature is often referred to as the "commitment 
approach" to explaining the role of trade agreements. The possibility for governments to gain from committing to certain policies is well-known from a number of strands in the economic literature, as well as from actual policymaking. For instance, this notion is an important reason why many governments have left the control over monetary policy to independent central banks.

We will briefly present two illustrations of how a commitment mechanism may help a government in the context of its trade-policy setting. We will then explain why we believe the commitment approach should be seen as complementing the national market power approach, rather than as being an alternative explanation for the existence of trade agreements.

Example 1: Suppose that wages in an industry are influenced by the actions of a labor union. The union can push up wages in order to increase incomes for employed members, but doing so will also tend to create unemployment. The unemployment would be mitigated, however, if the government subsequently imposes a tariff. The union finds most desirable an outcome that combines high wages tariff protection. But it prefers lower wages to high wages in the absence of import protection in recognition of the unemployment that high wages would then cause. The government in turn prefers low wages and free trade. But it will protect the industry with a tariff when wages are high, to avoid unemployment. In such a setting, and absent any commitment to trade policy, the labor union will push up wages, to exploit the government's aversion against unemployment, and the government will respond by protecting the domestic industry.

Now suppose that the government can commit to free trade by entering into a trade agreement. If the union sees the agreement as credible and binding, it will know that the government has no discretion to respond to the threat of high unemployment with protection. Realizing that high wages will cause unemployment, the union will now opt for lower wages. The outcome with the agreement will thus be more favorable to the government, since it can avoid unemployment without having to bear the associated costs of the protection.

The example is special, but illustrates two more general points. First, the government benefits from the commitment that the agreement provides: the fact that the government can no longer control the tariff policy changes the incentives facing the union, causing it to take actions that are beneficial to the government's interests. Second, this benefit from the agreement does not hinge on any exploitation of national market power. Indeed, we could assume that the country in the example is "small" in the sense discussed above, thus completely removing any national market power motivation for imposing a tariff. 
The agreement would still be beneficial to the government, by affecting the behavior of the union.

Example 2: Suppose that a government derives welfare both from domestic social welfare, as well as from the campaign contributions. The campaign contributions are offered by the import-competing sector in return for promises of protection. The industry benefits more from protection the more capital is invested there, and therefore the contributions vary with the size of the industry capital stock. If the government makes no commitments about its trade policy, the opportunity that the industry has to lobby for protection will lure capital to the import-competing industry, which in turn will induce the government to grant a high level of protection. If the government instead enters a trade agreement that compels free trade, the investment in the import-competing sector will be smaller and the industry's motive for campaign contributions will vanish. From the government's perspective, the loss of contributions is a negative consequence of the commitment, but the deterrence to overinvestment in the industry is a potential benefit. Depending on the weights in the government's objective function, it may prefer an outcome with zero contributions but a smaller resource misallocation to one with positive contributions but a gross misallocation of capital. ${ }^{40}$

These two examples thus show how a restriction on a government's ability to freely choose its future policy actually benefits the government by changing the behavior of private interest groups with which it interacts. The trade policy literature contains other examples of situations in which governments may benefit from a similar type of commitments. ${ }^{41}$ The unifying theme is that the commitments solve a "time consistency" problem for the government: the government prefers ex ante the outcome that results from a "tough" stance ex post, but a mere threat to act tough is not effective, because the interest group knows that the government would not actually wish to carry out the threat. By signing a trade agreement that locks in its future level of protection, the government buys credibility for its threat to act tough, and so can induce better behavior from the special interests.

The commitment approach is often seen as representing a conceptually distinct explanation for why countries form trade agreements, since it does not rely on international externalities. But this does not seem to us to be correct. The basic idea is of the commitment approach is that governments will be punished by trade partners, should they increase tariffs beyond bound levels. But how can such punishment be administered if countries lack market power? If the deviating importing country is small, trade partners

\footnotetext{
40 This is an extremely simplified account of the Maggi and Rodríguez-Clare (1998) model.

41 See, for instance, Maggi and Rodríguez-Clare (2007) and references cited there.
} 
would not be affected by the deviation, and would for this reason have little incentive to impose retaliatory tariffs that would be costly to itself. And if the trade partner is small, the imposition of retaliatory tariffs would be ineffective, since it would not hurt the deviating import country. It thus appears that in order for the commitment to be effective, both the country making the commitment, and the trade partners that are to enforce it, must have some national market power.

It should also be noted that several core features of the GATT/WTO seem difficult to understand were commitment the only reason for a trade agreement:

1. If there is one single feature that more than anything else characterizes multilateral trade liberalization, it is the difficulty to find mutually acceptable concessions in terms of tariff cuts and adoption of regulations. Countries seem genuinely unwilling to liberalize unilaterally, and they seem to desire other countries to liberalize.

2. As argued by Ethier (2001), many of the rules concerning dispute settlement in the GATT/WTO restrict the possibilities for members to take countermeasures. For instance, countermeasures cannot be taken by other members than those affected by an illegality; countermeasures typically come with a significant delay because of the need to go through the formal process of adjudication, and a recalcitrant responding country can, through legal measures, delay countermeasures by several years; and when countermeasures are finally imposed, they have to be commensurate with the ongoing deviation.

3. The GATT/WTO incorporates several forms of safeguards that allow members to escape their commitments. While it would be possible to construct a rationale for safeguards in a commitment contract, it does appear as if the scope to use them would be more limited than if the purpose of the agreement were to internalize externalities.

4. If the purpose of the GATT/WTO were to serve as a commitment device, the legal text would presumably insist on the obligations of the parties toward the other parties. There are indeed frequent references to obligations, but these obligations create rights for other parties, not restrictions on what they can do. Indeed, Art. XXIII GATT, which specifies the circumstances under which a member can successfully pursue a complaint against another member, reads:

"If any contracting party should consider that any benefit accruing to it directly or indirectly under this Agreement is being nullified or impaired...."

This core provision gives a right to a member to take action if the member believes that its rights have been denied. It does not request the member to do so, should other parties fail to live up to their obligations. Of course, it could be argued that if trade partners always protected their interests, the two things would amount to the same 
thing in practice. But it would still seem odd that an agreement purportedly serving the role of a commitment device, should instead emphasize the rights of trade partners.

5. Related to the previous point, Art. XXIII GATT only allows a member to take countermeasures when benefits accruing to this member have been nullified or impaired, that is, when it has been adversely affected by another member. But, as was argued above, if countries are small, how could a deviation by a single member affect trade partners? This fundamental provision indeed seems squarely designed to address situations where there are externalities of some form, but the commitment approach alone does not explain what these are.

To conclude, the commitment approach captures interesting aspects of the interaction between governments and their constituent interests. But it does not provide an independent explanation for the existence trade agreements; it should thus better be seen as complementing some form of national market power approach. While there may well be countries that have acceded to the WTO in order to achieve commitment, this cannot be true for all of the countries in the multilateral system, or even for the largest and most important members of the WTO.

\section{Concluding Remarks}

The purpose of this study has been to introduce the reader to an approach used by most economists to study trade agreements - what we denoted as the international externalities approach. The analytical core of this approach is the notion that governments expose one another to externalities when they set their trade policies unilaterally, and that trade agreements provide a way to help governments coordinate on more efficient outcomes. Section 3 illustrated this idea in a very general form, making only a few assumptions about the functioning of the economy and political systems of the trade partners under study. The section also discussed several intrinsic features of trade agreements, such as the fact that they are negotiated, reciprocal, self-enforcing, explicit, and incomplete.

The depiction of trade agreements in Section 3 illustrated the basic externality problem that trade agreements address, but it was too general to yield any more specific predictions concerning the properties of equilibrium agreements or outcomes. Section 4 described how the international externalities approach is typically operationalized within a particular model of the economy and polity. The section first laid out the simplest model of trade-agreement formation, which assumes national income maximizing governments and perfectly competitive markets. In this setting, governments impose negative externalities in their attempts to exert their national market power. We argued 
that the simple baseline model can be modified to capture more realistic economic structures and government objectives, and that the model is compatible with many core features of the GATT. But we also discussed some of the criticism that has been directed toward the model, and noted that certain features of the GATT are hard to reconcile with the model. Finally, Section 5 briefly discussed the commitment approach, which often is seen as the main alternative explanation to the role of trade agreements. But as argued, this approach should rather be seen as a complement to the national market power approach.

So where does this leave us? In our view, the fundamental rationale for the GATT is to help governments avoid externalities from unilateral determination of policies. These externalities arise when governments reduce import demand in order to achieve their domestic policy objectives. When import demand is reduced, exporters face lower prices for any volume they sell, and they sell smaller volumes for any price they charge, and as a consequence export less. A reduced import demand is not necessarily negative, as a matter of theory - a reduction may be desirable for instance if the consumption of imports causes environmental harm. However, since the full costs of tariffs are not factored into governments' unilateral decisions, tariffs will typically be set too high from a global point of view. In such circumstances, reciprocal reductions of tariffs can be found that benefit all governments. The central role of the GATT is to help governments achieve this. This vision of the role of GATT can be harbored reasonably well within the national market power approach. 


\section{References}

Bagwell, Kyle. 2009. Self-Enforcing Trade Agreements and Private Information, NBER Working Paper 14812, National Bureau of Economic Research, Inc.

Bagwell, Kyle, and Robert W. Staiger. 1999. An Economic Theory of the GATT. American Economic Review 89(1), pp. 215-248.

Bagwell, Kyle, and Robert W. Staiger. 2002. The Economics of the World Trading System, MIT Press : Cambridge, Mass.

Bagwell, Kyle, and Robert W. Staiger. 2005. Enforcement, Private Political Pressure and the GATT/WTO Escape Clause, The Journal of Legal Studies 34(2).

Bagwell, Kyle, and Robert W. Staiger. 2006. Will International Rules on Subsidies Disrupt the World Trading System?, American Economic Review, 96(3), June 2006, pp. 877895(19).

Bagwell, Kyle, and R. W. Staiger. 2009a. Profit Shifting and Trade Agreements in Imperfectly Competitive Markets, NBER Working Paper 14803.

Bagwell, Kyle, and R. W. Staiger. 2009b, Delocation and Trade Agreements in Imperfectly Competitive Markets, unpublished manuscript, Stanford University.

Bagwell, Kyle, and Robert W. Staiger. 2011. What Do Trade Negotiators Negotiate About? Empirical Evidence from the World Trade Organization. American Economic Review 101(4), pp. 1238-1273.

Bagwell, Kyle, and Alan O. Sykes. 2004. Chile - Price Band System and Safeguard Measures Relating to Certain Agricultural Products, in Henrik Horn and Petros C.

Mavroidis (eds.), The WTO Case Law of 2002: The American Law Institute Reporters' Studies, Cambridge: Cambridge University Press.

Bickerdike, Charles 1906. The Theory of Incipient Taxes, Economic Journal XVI (December), pp. 529-535.

Broda, Christian, Nuno Limão, and David E. Weinstein, 2008. Optimal Tariffs and Market Power: The Evidence. American Economic Review 98(5), pp. 2032-2065. 
Chisik, Richard. 2003. Gradualism in Free Trade Agreements: a Theoretical Justification, Journal of International Economics 59(2), pp. 367-397.

Copeland, Brian R., 1990. Strategic enhancement and destruction of fisheries and the environment in the presence of international externalities, Journal of Environmental Economics and Management 19(3), pp. 213-226.

Crowley, Meredith A., and David Palmeter. 2009. Japan - Countervailing Duties on Dynamic Random Access Memories from Korea (DS 336 and Corr.1, adopted 17 December 2007), World Trade Review 8(1), pp. 259-272.

Dixit, Avinash K., and John Londregan. 1996. The Determinants of Success of Special Interests in Redistributive Politics, Journal of Politics 58, pp. 1132-1155.

Ethier, Wilfred J. 2001. Theoretical problems in negotiating trade liberalization, European Journal of Political Economy 17(2), pp. 209-232.

Ethier, Wilfred J. 2004. Political Externalities, Nondiscrimination, and a Multilateral World, Review of International Economics 12(3), pp. 303-320.

Ethier, Wilfred J. 2006. The Theory of Trade Policy and Trade Agreements: A Critique, Penn Institute for Economic Research Working Paper 06-013.

Ethier, Wilfred J. 2011. The Political Economy of Protection, in Bernhofen, Daniel, Rod Falvey, David Greenaway, and Udo Kreickemeier (eds.), Palgrave Handbook of International Trade.

Grossman, Gene M., and Elhanan Helpman. 1994. Protection for Sale, American Economic Review 84(4), pp. 833-850.

Grossman, Gene M., and Elhanan Helpman. 1995a. Trade Wars and Trade Talks, Journal of Political Economy 103(4), pp. 675-708.

Grossman, Gene M., and Elhanan Helpman. 1995b. The Politics of Free-Trade Agreements, American Economic Review 85(4), pp. 667-690.

Grossman, Gene M., and Petros C. Mavroidis. 2003. United States - Imposition of Countervailing Duties on Certain Hot-Rolled Lead and Bismuth Carbon Steel Products Originating in the United Kingdom: Here Today, Gone Tomorrow? Privatization and the 
Injury Caused by Non-Recurring Subsidies, The WTO Case Law of 2001: The American Law Institute Reporters' Studies, Cambridge: Cambridge University Press, pp. 170-200.

Grossman, Gene M., and Petros C. Mavroidis. 2004a. United States - Definitive Safeguard Measures on Imports of Circular Welded Carbon Quality Line Pipe from Korea, in Henrik Horn and Petros C. Mavroidis (eds.), The WTO Case Law of 2002: The American Law Institute Reporters' Studies, Cambridge: Cambridge University Press.

Grossman, Gene M., and Petros C. Mavroidis. 2004b. United States - Countervailing Measures Concerning Certain Products from the European Communities: Recurring Misunderstanding of Non-Recurring Subsidies, in Henrik Horn and Petros C. Mavroidis (eds.), The WTO Case Law of 2002: The American Law Institute Reporters' Studies, Cambridge: Cambridge University Press.

Grossman, Gene M., and Alan O. Sykes. 2006. United States - Definitive Safeguard Measures on Imports of Certain Steel Products, in Henrik Horn and Petros C. Mavroidis (eds.), The WTO Case Law of 2003: The American Law Institute Reporters' Studies, Cambridge: Cambridge University Press.

Grossman, Gene M., and Alan O. Sykes. 2011. 'Optimal' Retaliation in the WTO - a commentary on the Upland Cotton Arbitration, World Trade Review 10, pp. 133-164.

Herzing, Mathias. 2005. Essays on Uncertainty and Escape in Trade Agreements, Monograph No. 50, Institute for International Economic Studies, Stockholm University.

Hillman, Arye L., and Peter Moser. 1996. Trade Liberalization as Politically Optimal Exchange of Market Access, in Canzoneri, Mathew, Wilfed J. Ethier, and Vittorio Grilli (eds.), The New Transatlantic Economy, Cambridge: Cambridge University Press, pp. 295-312.

Hoda, Anwarul. 2001. Tariff Negotiations and Renegotiations under the GATT and the WTO: Procedures and Practices, Cambridge: Cambridge University Press.

Hoekman, Bernard, and Robert L. Howse. 2008. EC - Sugar, World Trade Review, Cambridge University Press, vol. 7(01), pages 149-178.

Hoekman, Bernard M., and Michel M. Kostecki. 2009. The Political Economy of the World Trading System: The WTO and Beyond, Oxford University Press. 
Horn, Henrik. 2006. National Treatment in Trade Agreements, American Economic Review 96(1), pp. 394-404.

Horn, Henrik, and Petros C. Mavroidis. 2001. Legal and Economic Aspects of MFN, European Journal of Political Economy 17, pp. 233-279.

Horn, Henrik, and Petros C. Mavroidis. 2004a. US Safeguard Measures on Imports of Fresh, Chilled or Frozen Lamb Meat from New Zealand and Australia: what should be required of a safeguard investigation?, World Trade Review 2(3), pp. 395-430.

Horn, Henrik, and Petros C. Mavroidis. 2004b. United States - Preliminary Determination with Respect to Certain Softwood Lumber from Canada: What is a Subsidy?, in Henrik Horn and Petros C. Mavroidis (eds.), The WTO Case Law of 2002: The American Law Institute Reporters' Studies, Cambridge: Cambridge University Press.

Horn, Henrik, and Petros C. Mavroidis. 2006. United States - Final Determination with Respect to Certain Softwood Lumber from Canada. In Henrik Horn and Petros C.

Mavroidis (eds.), The WTO Case Law of 2002: The American Law Institute Reporters' Studies, Cambridge: Cambridge University Press.

Horn, Henrik, Giovanni Maggi, and Robert W. Staiger. 2010. The GATT as an Endogenously Incomplete Contract, American Economic Review 100(1), pp. 394-419.

Hungerford, Thomas L. 1991. GATT: A cooperative equilibrium in a noncooperative trading regime?, Journal of International Economics 31 (3-4), pp. 357-369.

Janow, Merit E., and Robert W. Staiger. 2003a. United States - Measures Treating Export Restraints as Subsidies, in Henrik Horn and Petros C. Mavroidis (eds.), The WTO Case Law of 2001: The American Law Institute Reporters' Studies, Cambridge: Cambridge University Press, pp. 201-235.

Janow, Merit E., and Robert W. Staiger. 2003b. Canada - Measures Affecting the Importation of Dairy Products and the Exportation of Milk, in Henrik Horn and Petros C. Mavroidis (eds.), The WTO Case Law of 2001: The American Law Institute Reporters' Studies, Cambridge: Cambridge University Press, pp. 236-280.

Johnson, Harry G. 1953-1954. Optimum Tariffs and Retaliation, Review of Economic Studies 21, pp. 142-153. 
Lerner, Abba P. 1936. The Symmetry Between Import and Export Taxes, Economica 3(11), pp. 306-313.

Mayer, Wolfgang. 1981. Theoretical Considerations of Negotiated Tariff Adjustments, Oxford Economic Papers 33, pp. 135-153.

Magee, Stephen P. 1994. Endogenous Protection: A Survey, in: Mueller, D. C. (ed.), Handbook of Public Choice, (Cambridge, MA: Basil Blackwell).

Maggi, Giovanni, and Andrés Rodriguez-Clare. 1998. The Value of Trade Agreements in the Presence of Political Pressures, Journal of Political Economy 106(3), pp. 574-601.

Maggi, Giovanni, and Andrés Rodríguez-Clare. 2007. A Political-Economy Theory of Trade Agreements, American Economic Review 97(4), pp. 1374-1406.

Nelson, David. 1988. Endogenous Tariff Theory: A Critical Survey, American Journal of Political Science 32, pp. 796-837.

Ossa, Ralph. 2011. Trade Wars and Trade Talks with Data. NBER Working Paper Series No. 17347, Boston, Mass.

Regan, Donald H. 2006. What Are Trade Agreements For? - Two Conflicting Stories Told by Economists, With a Lesson for Lawyers, Journal of International Economic Law 9(4), pp. 951-988.

Rodrik, Dani. 1995. Political Economy of Trade Policy, in Grossman, G., and K. Rogoff (eds.), Handbook of International Economics III, Amsterdam: North-Holland, pp. 14571495.

Saggi, Kamal, and Nese Sara. 2008. National Treatment at the WTO: The Roles of Product and Country Heterogeneity, International Economic Review 49(4), pp. 1365-1394.

Sapir, Andre, and Joel P. Trachtman. 2008. Subsidization, price suppression, and expertise: causation and precision in Upland Cotton, World Trade Review 7(1), pp. 183209.

Schropp, Simon. 2009. Trade Policy Flexibility and Enforcement in the WTO: A Law \& Economics Analysis, Cambridge University Press. 
Schwartz, Warren F., and Alan O. Sykes. 2002. The Economics Structure of Renegotiation and Dispute Resolution in the WTO/GATT System, Journal of Legal Studies 31(1), pp. 179-204.

Staiger, Robert W. 1995. International Rules and Institutions for Trade Policy, in Grossman, Gene M., and Kenneth Rogoff (eds.), Handbook of International Economics III, Amsterdam: North-Holland, pp. 1495-1551.

Sykes, Alan O. 2005. The Economics of WTO Rules on Subsidies and Countervailing Measures, in A. Appleton, P. Macrory \& M. Plummer eds., The World Trade Organization: Legal, Economic and Political Analysis, Vol. II, New York: Springer Verlag.

WTO. 2008. World Trade Report 2008: Trade in a Globalizing World, World Trade Organization, Geneva. 